\title{
Review
}

\section{Studies of Depression-Related States in Animal Models of Parkinsonism}

\author{
Nicoletta Schintu*, Xiaoqun Zhang and Per Svenningsson* \\ Translational Neuropharmacology, Center for Molecular Medicine, Department of Clinical Neuroscience, \\ Karolinska Institute, Stockholm, Sweden
}

\begin{abstract}
The diagnosis of Parkinson's disease (PD) is solely based on movement disorders, but several non-motor deficits are common in PD. Depression often precedes the movement dysfunctions and continues to be a major concern during all stages of the disease. The pathophysiology of parkinsonian depression is largely unknown, but appears to partly differ from depression in patients without PD. Because of the increased awareness of the negative impact of depression on the quality of life of PD patients, there is a growing interest in developing animal models of parkinsonism that also recapitulate the depressive-like symptomatology. This review introduces paradigms for measurement of depression-like behaviors in rodents and summarizes data on behavioral, neurochemical and pharmacological changes in experimental PD models with relevance for depression-related states.
\end{abstract}

Keywords: Parkinson's disease, anhedonia, dopamine, serotonin, neurogenesis

\section{INTRODUCTION}

Parkinson's disease (PD) is the second most common neurodegenerative disorder next to Alzheimer's disease; with an annual incidence ranging from 110 to 330 cases per 100,000 individuals over the age 50 [1]. The diagnostic symptoms of PD are bradykinesia, accompanied by at least one of the three additional symptoms: rigidity, rest tremor and/or disturbance of postural reflexes. These motor symptoms are primarily due to the loss of dopaminergic neurons that project from the substantia nigra pars compacta $(\mathrm{SNc})$ to the striatum and are treated with pharmacological agents which stimulate dopamine (DA) transmission. Most animal models of PD have employed toxins or genetic manipulations to recapitulate the motor symptomatology $[2,3]$. However, it has long been recognised

*Correspondence to: Nicoletta Schintu or Per Svenningsson, Translational Neuropharmacology, Center for Molecular Medicine, Department of Clinical Neuroscience, Karolinska Institute, Stockholm 171 76, Sweden. Tel.: +46 8 5174614; Fax: +46 8 5174614; E-mails: nicoletta.schintu@ki.se (Nicoletta Schintu) or per.svenningsson@ki.se (Per Svenningsson). that the neuropathology underlying PD involves many brain areas beyond the dopaminergic nigrostriatal system, including areas that are not directly involved in motor control. These areas include the mesolimbic dopaminergic system, noradrenergic neurons in locus coeruleus, serotonergic neurons in the raphe nuclei, cholinergic neurons in the nucleus Basalis of Meynert, the dorsal vagal nucleus, the olfactory tubercle and large parts of the limbic cortex and neocortex [4]. Changes in the abovementioned systems may underlie many of the non-motor symptoms associated with PD.

Depression is the most frequent psychiatric complication in PD patients and one of the most important factors that reduce quality of life in PD [5]. Currently in Europe, there are approximately 1,000,000 patients with PD and between $36-53 \%$ of these patients also suffer from depression [5]. It has been argued that depression in PD is merely reactive to disability and loss of independent function, but about $20 \%$ of patients diagnosed with PD suffer from ongoing depression [6]; this may indicate that depression is part of the disease process rather than a result of diagnosis or living with PD. Studies have shown that people with PD have 
higher levels of depression than people with similar levels of disability from other causes (e.g. paraparesis), indicating that depression may be a part of PD itself [7]. It should be noted that it is difficult to diagnose depression in patients with PD because of the overlapping symptoms of the two disorders. Indeed, sleep disturbances, cognitive impairments, such as difficulties with concentration, and fatigue are also observed in non-depressed patients with PD, whereas typical symptoms of depression, like psychomotor retardation, bradykinesia and reduced mimic movements may also represent neurological deficits caused by PD. The high incidence of non-motor symptoms in PD, particularly depression, emphasizes the importance of studies of non-motor symptomatology in animal models to improve our understanding of pathophysiological mechanisms and possible treatments.

Here, we will introduce behavioral tests designed to assess depressive-like phenotypes in rodents and summarize data obtained with these tests in animal models of PD. The role of neurotransmitters, neurotrophic factors, steroids, neurogenesis and inflammation in depression and PD will then be briefly discussed (see summary in Fig. 1).

\section{ANIMAL TESTS AND MODELS FOR DEPRESSION-LIKE SYMPTOMS}

It should be acknowledged that it is very difficult to recapitulate behaviors of depression in rodents. There are, however, tests that can evaluate the potential presence of depression-related states. The most widely used tests, such as forced swim (FST) or tail suspension test (TST), were originally developed to detect behavioural responses to pharmacological antidepressant treatments. These tests have predictive validity for monoaminergic antidepressants. On the other hand, other experimental protocols such as chronic mild unpredictable stress (CUS) or social defeat are considered better animal models because they do not only have predictive validity, but also important aspects of face and construct validities. One important confounder, which needs to be kept in mind when studying a depressive-like state in PD models, is that most of the paradigms have a motor component. It is therefore critical to perform both the depression-related test and a pure motor test, for example in a locomotor box, under the same treatment conditions. However, in many instances more sensitive tests are needed to clearly elucidate motor skills in rodents. For example, depressive-like tests and models could be coupled with analyses of motor performances in the pole test, beam traversal test, skilled limb use and stepping test [for protocols see 8-10]. Another important aspect in depression-related tests and models is that they often involve a component of anxiety. In humans, these two disorders are often comorbid, although the underlying neuronal circuitries are thought to be partially distinct [11].

Several paradigms are used in the field of experimental depression research, but, as indicated below and in Table 1, only few of them have been applied to PD models.

\section{Forced swim test}

Porsolt and collaborators described in 1977 "a new behavioural method for inducing a depressed state", which is, despite some weaknesses, still the most widely used animal test in depression research [12]. The paradigm is based on placing rodents, mice or rats, in a cylinder filled with water from which they

Table 1

Summary of different PD models in which a particular depression-like test has been used. Abbreviations: FST: forced swim test, TST: tail suspension test, LH: learned helplessness, NIH: novelty-induced hypophagia, NSF: novelty-suppressed feeding; ICSS: intracranial self-stimulation, CUS: chronic unpredictable stress, OB: Olfactory bulbectomy. ND: Not done

\begin{tabular}{|c|c|c|c|c|c|c|c|c|}
\hline & 6-OHDA & MPTP & rotenone & LPS & Reserpine & Parkin deficient & VMAT-2 deficient & VMAT-2 HET \\
\hline FST & $+[31,33,34,36]$ & $+[36]$ & $+[36]$ & $\begin{array}{c}-[36] \\
+[214,215]\end{array}$ & $+[52]$ & $-[63]$ & $+/-[67]$ & $+[69]$ \\
\hline TST & ND & $\begin{array}{l}+[43] \\
-[44]\end{array}$ & ND & $+[215]$ & ND & $-[63]$ & $+/-[67]$ & $+[69]$ \\
\hline LH & $+[37]$ & ND & ND & ND & ND & ND & ND & $+[69]$ \\
\hline NIH/NSF & ND & ND & ND & ND & ND & ND & ND & $-[69]$ \\
\hline Sucrose preference & $\begin{aligned}+ & {[31,36] } \\
& -[33]\end{aligned}$ & $\begin{array}{l}+[36] \\
-[44]\end{array}$ & $+[36]$ & $-[36]$ & $+[51]$ & ND & ND & $+[69]$ \\
\hline ICSS & ND & ND & ND & $+/-[216]$ & ND & ND & ND & ND \\
\hline CUS & ND & ND & ND & ND & ND & ND & ND & ND \\
\hline Social defeat & ND & ND & ND & ND & ND & ND & ND & ND \\
\hline OB & ND & ND & ND & $+[217]$ & ND & ND & ND & ND \\
\hline
\end{tabular}


cannot escape. Different types of behavior can then be measured: immobility as an indication of "behavioural despair", swimming and climbing [13]. Acute antidepressants can significantly reduce the time spent immobile [14]. Interestingly, drugs acting on different neurotransmitters systems seem to affect different active behaviours. Swimming is sensitive to serotonergic compounds, such as the selective serotonin reuptake inhibitors (SSRIs) and serotonin receptor agonists, while climbing is more affected by tricyclic antidepressants (TCAs) and noradrenergic compounds [15].

\section{Tail suspension test}

The TST is another test of "behavioural despair", but restricted to mice. The TST set-up consists of a horizontal bar where mice are suspended by tape at the tip of their tails [16]. In the TST, as in the FST, immobility is measured and significantly counteracted by acute antidepressant treatments [17]. However, recent studies showed that drugs tested in the TST for antidepressant properties showed strain-dependent effects. For example, the baseline and imipramine-induced behaviors of 11 different strains of mice showed clear inter-strain differences for both baseline scores and response to imipramine. In fact, a reduced immobility, i.e. positive antidepressant-like effect, of imipramine was only found in three strains (DBA/2J, NMRI and FVB/NJ) [18]. TST and FST were developed to detect antidepressant responses to monoaminergic antidepressants, but may disregard antidepressant potential of non-monoaminergic compounds. Moreover, in these tests an acute stressor is applied to normal animals while human depression involves long-lasting complex interactions between genetic and environmental factors. Furthermore, in the TST and FST a positive outcome is found already after a single administration of an antidepressant, while there is a considerable time (weeks-months) lag of response to the same antidepressant treatment in depressed patients. These limitations reduce the relevance of TST and FST.

\section{Novelty-suppressed feeding (NSF) and}

Novelty-induced hypophagia (NIH)

The conflict between an anxious situation and an inherent need to feed is measured in the NSF test. The latency to eat a pellet in the center of a brightly lit novel cage by a food-deprived rodent is measured. As a control for hunger, the amount of pellet consumption is subsequently measured in the home cage. In this test, hyponeophagia, i.e. inhibition of feeding produced by exposure to novelty, is an assessment of the anxietyrelated component of depression [19]. To avoid the food deprivation, a modified paradigm called NIH has been introduced. Although this test has been developed for mice, it may be adapted for use with other species. In the NIH test, animals are trained to drink sweetened condensed milk for three consecutive days in their home cage. The latency to drink, and the volume consumed are then recorded every $5 \mathrm{~min}$ for $30 \mathrm{~min}$ in the home cage during the 4 th day and in a novel cage during the following day [20]. Interestingly, both these tests are sensitive to chronic, but not acute, antidepressant treatments [19].

\section{Sucrose preference}

This test is used as a measurement of anhedonia, which has been described as "markedly diminished interest or pleasure in all, or almost all, activities most of the day, nearly every day", considered as one of the core symptoms of depression [21]. The test measures the preference for, and consumption of, $1-2 \%$ sucrose solution over water in a two bottle choice setting. Anhedonic-like rodents show decreased preference for the sucrose solution, probably due to a reduced sense of reward of the sweet taste [22]. This test, practically easy to perform, is of particular importance in the characterization of the depressive-like phenotype of a PD model. Unlike many other tests, sucrose preference does not have a motor component as a possible confounder since it measures the percentage of sucrose consumption. Moreover, it has important face validity since anhedonia is a core symptom of depression not least in PD patients.

\section{Intracranial self-stimulation (ICSS)}

Another measure of the hedonic drive and its relation to the reward pathways is ICSS. Since brain regions, such as nucleus accumbens, hippocampus and amygdala, implicated in the human depression are also involved in the rodents' response to ICSS, this test could be relevant to study depressive-like behaviors [23]. The experimental procedure involves the surgical implantation of electrodes into one of the abovementioned brain regions of rats or mice. Animals are then trained to perform an active action to obtain rewarding electrical stimulations. The number of actions measures the sensitivity of the reward system and goaloriented motivation [24]. In the ICSS paradigm, the stimulation does not induce any tolerance so measurements can be obtained over long periods of time [23]. 


\section{Learned helplessness (LH)}

In the LH model, mice or rats undergo an exposure phase during which they receive repeated unpredictable electric shocks (or other stressors) from which they cannot escape. On the day of test, when the animals have the possibility to escape after the shock, many of them choose not to do so. The escape deficit has been found to be reversible by both acute and chronic antidepressant treatments. The major criticisms of this test is that only a small percentage of exposed animals develop an escape deficit and that there are some strains of mice with an escape deficiency independent to stress exposure [25]. Since an active motor response is required from the tested animals, it is of particular importance to, in parallel, properly study the locomotor performance.

\section{Chronic unpredictable stress}

Much work in animal models follows the notion that experiences of stressful events, especially if repeated and unpredictable, are potent risk factors for developing depression. CUS involves exposing rodents to a series of repeated stressors (including swimming, strong light, cold, restrain, shocks) over several weeks [26]. After these stressors, animals develop a depression- and anhedonia-like phenotype, measured by for example sucrose preference reduction, that can be reversed by chronic, but not acute, antidepressant treatments.

\section{Social defeat}

In the social defeat model, the stress of the studied rodent is caused by the daily fighting with a physically superior and novel aggressor rodent. After some days, the defeated rodent develops common depression-like symptoms including anhedonia and social avoidance [27], which can be reversed by chronic, but not acute, antidepressant treatments [28].

\section{Olfactory bulbectomy $(O B)$}

The surgical removal of olfactory bulbs has been shown to induce increased locomotor activity and an avoidance-learning deficit in rodents that can be reversed by chronic antidepressants [29]. These symptoms seem to be caused by dysfunction of the hippocampal-amygdala pathway.

\section{STUDIES OF THE DEPRESSION-LIKE PHENOTYPE IN ANIMAL MODELS OF PARKINSONISM}

\section{Classic neurotoxins-based models}

\section{6-hydroxydopamine (6-OHDA)}

The neurotoxin 6-OHDA has played a fundamental role in preclinical research on PD [30]. Neurotoxic effects of 6-OHDA occur through a two-step mechanism involving accumulation of the toxin into catecholaminergic neurons, followed by alteration of cellular homeostasis and neuronal damage. Different 6-OHDA-based rodent models in which the toxin is variably injected into the nigrostriatal pathway (i.e. $\mathrm{SNc}$, median forebrain bundle and striatum) have been developed throughout the years. These models result in moderate to complete nigrostriatal neurodegeneration, thus providing appropriate paradigms for modeling of distinct parameters, from molecular markers to fine motor symptoms of PD. Only recently, this model has been used to study depression-like behaviors in PD and reported results are different depending on the chosen lesion paradigm. Bilateral 6-OHDA infusion in the striatum caused a fast damage of the dopaminergic terminals with about $59 \%$ of striatal DA loss, followed by retrograde loss of tyrosine hydroxylase $(\mathrm{TH})$-positive cells in the SNc [31]. Under these circumstances, the SNc cell loss takes place gradually over several weeks [32]. This progression in nigral degeneration creates a time window that can be used for the investigation of pre-motor symptoms of PD. In this model, reduced sucrose consumption and increased immobility in the FST were found, despite that the locomotor activity was not impaired. However, no sensitive fine movement tests were performed in this study to properly assess motor deficits. Another study also found that a mild bilateral striatal lesion (36\% striatal DA loss) caused increased immobility in the FST, but in this case without any effect on sucrose consumption [33]. In this study [33] the alteration in the FST was found 6 weeks after the intrastriatal 6-OHDA lesion, whereas a motor impairment in the locomotor activity was found after 9 weeks. In this 6-OHDA paradigm, emergence of impairments seems to follow a temporal profile similar to that occurring in PD patients. Recently, the contribution of a severe 6-OHDA lesion ( $>95 \%$ DA loss in striatal tissue) on FST was studied by using a unilateral medial forebrain bundle lesion model [34, 35 ] and evidence of a depression-like behavioral profile was observed. However, the severity of the lesion resulted in significant motor disability, which makes 
extrapolations to affective processes difficult. In general, unilateral models are difficult to interpret because the responses of the animals can result from a contralateral compensation or a bias towards movements in one direction. By bilaterally injecting the neurotoxin directly into the SNc and achieving a 50\% nigral neuronal loss without affecting other areas, it has been shown that rats develop both anhedonia, measured by sucrose consumption, and behavioral despair in the FST [36]. Likewise, unilateral 6-OHDA lesion of the $\mathrm{SNc}$ resulted in depressive-like behaviors using the $\mathrm{LH}$ model in rats [37]. These authors found similar results when injecting 6-OHDA unilaterally into the ventral tegmental area (VTA) suggesting an involvement of the mesolimbic DA pathway in depression.

\section{1-methyl-4-phenyl-tetrahydropiridine (MPTP)}

The incidence of PD is known to be associated with exposure to a wide range of environmental, industrial and agrochemical toxins as well as accidentally produced narcotics. Ingestion or administration of some of those agents to rodents can induce neurodegeneration with rather selective vulnerability of ventral mesencephalic DA neurons accompanied by behavioral deficits. Among these agents, MPTP has received most attention as an experimental tool for modeling PD. The propensity of MPTP to cause a parkinsonian syndrome was discovered in drug addicts who mistakenly self-administered the compound after a poorly conducted chemical synthesis of a designer drug of abuse [38]. The compound is widely used in mice and non-human primates while it has a limited toxicity in rats due to differences in the ability to convert MPTP to MPP+ ion, the active form of the toxin. Several different protocols are used with different outcomes in terms of motor impairments. The acute protocol, usually based on 4 intraperitoneal injections of $20 \mathrm{mg} / \mathrm{kg}$ of MPTP given 2 hours apart, has resulted in inconsistent data in motor impairments [39-42]. To try to find a more reliable test than locomotion to study motor impairment in this model, Mori and collaborators used the TST and found increased immobility time, but preserved locomotion, in toxin-treated mice [43]. The increased immobility in the TST was counteracted by dopaminergic stimulants, such $\mathrm{D}_{2}$ receptor agonists and L-DOPA. $\mathrm{D}_{2}$ receptor agonists, but less so L-DOPA, have antidepressant properties (see below), indicating that the found immobility under baseline conditions may represent motor dysfunction rather than a depression-like phenotype. In this context, it is important to keep in mind that the TST is not a valid test of motor function. One study using the same MPTP treatment paradigm in mice reported no depressive-like behaviors in the TST and sucrose consumption tests [44]. In contrast, rats intracranially injected with MPTP in the SNc showed both anhedonia and behavioral despair [36]. The conflicting data of the abovementioned studies probably relates to different neurotoxin lesioning paradigms, time after lesion and species used. In contrast to the acute model, the chronic paradigm of MPTP administration, such as twice per week for 5 weeks, seems to provide more reproducible results on tests of motor impairment [10,45]. At the moment, no studies have been done to characterize the depressivelike behaviors in the chronic MPTP model.

\section{Other drug-induced models}

\section{Rotenone}

Rotenone is a pesticide that has attracted particular attention because it can, like MPTP, damage mitochondrial complex I in a pattern similar to what found in PD. However, several studies have pointed out the non-specific toxicity of rotenone paradigms suggesting the need of a careful use of this model and critical understanding of the outcomes when relating to parkinsonism [46, 47]. Bilaterally injected-toxin into the SNc was able to produce depressive-like behaviors assessed through the FST and the sucrose preference test in rats, although the involvement of a motor impairment may have confounded the FST results [36]. In this study, bilateral intranigral administration of LPS was also used to study FST. LPS stimulates neuroinflammatory processes and, under some circumstances, potentiates neurodegeneration and, as discussed below, there is evidence of a low-grade, but persistent, neuroinflammation in PD. However, intranigral LPS caused no significant behavioral alterations.

\section{Reserpine}

An old model of parkinsonism in rodents and rabbits is treatment with reserpine, which interferes with the storage of catecholamines in intracellular granules, resulting in monoamine depletion in nerve terminals and in the induction of hypolocomotion and muscular rigidity [48, 49]. Using reserpinized animals, it was shown that L-DOPA is the precursor of DA and has strong stimulatory locomotor properties [50]. Reserpinezed mice displayed a significant decrease in sucrose preference compared to vehicle treated mice whereas there was no difference in the total liquid consumption [51]. Moreover, rats treated with reserpine showed an increased immobility time in the FST at a 
dose that did not induce any locomotive impairment in the open-field test [52].

\section{Genetic models}

Most cases of PD are idiopathic with no evident genetic causality. However, familial PD has been identified and more than 11 loci and 16 genes have been reported [53]. The first familial PD mutation was in the $\alpha$-synuclein gene [54]. Subsequent work identified $\alpha$-synuclein as an abundant protein in the core of Lewy bodies [55], the globular protein inclusions in neurons considered the principal neuropathological hallmark of idiopathic PD. Later, mutations have been identified in several other genes, including leucine-rich repeat kinase 2 (LRRK2), Parkin, DJ-1, and PTEN-induced kinase 1 (PINK1). Although the incidence of familial $\mathrm{PD}$ is low, the identification of these genes and their protein products has provided important insight into the pathophysiology of PD. Several of these genes are associated with proteins components of the mitochondrial energy chain or implicated in protein folding and degradation via the ubiquitin-proteasome system [53].

Neurotoxin PD models reproduce the characteristic loss of dopaminergic neurons and result in motor impairments, but lack most of the other key characteristics of PD, such as the age-dependent progressive neuronal loss and the presence of Lewy bodies. Because of these limitations, major efforts have been made to generate new animal models of PD, particularly the creation of mutant mice expressing genetic alterations similar to those found in humans. $\alpha$-synuclein overexpression has attracted particular attention and several genetically-modified transgenic lines have been made using different promoters [56]. Unfortunately, none of the models fully replicate the neurodegenerative pattern or behaviors of PD. However, interesting studies performed in mice carrying a chromosomal deletion of the $\alpha$-synuclein locus showed that knock out (KO) animals have higher level of ICSS compared with control group. This effect can probably be attributed to a higher level of DA release in the mesolimbic terminals due to the larger vesicular capacity found in these mice [57]. An alternative procedure to overexpress $\alpha$-synuclein is viral vectormediated delivery to specific targets, such as the SNc. This strategy results in a model that more closely mirrors the PD pathology with neuronal inclusions [58]. So far, no studies have examined the depressive-like phenotype of this model. Several genetic lines carrying a deletion of different exons in the parkin gene have also been generated [59-62], but none of them showed a consistent phenotype, probably due to different genetic backgrounds. A mouse line lacking exon 2 of the parkin gene was investigated in terms of nonmotor behaviors, but no significant phenotypes were found in the FST and TST [63].

The recent report of a transgenic animal model of PD that carries the LRRK2 mutation has also attracted considerable interest [64] and genetic mouse models have recently been developed with mutated PINK1 and DJ1. Overall, in these genetic lines based on familiar PD, significant behavioral impairments have been difficult to observe and limited efforts have been made to study non-motor features of PD.

Within the context of genetic mouse lines, Mooslehner and co-authors generated a line expressing $5 \%$ of the normal level of the vesicular monoamine transporter 2 (VMAT2), which regulates packaging of not only DA, but also noradrenalin (NA) and serotonin (5-HT) into synaptic vesicles in neurons [65]. This line was characterized as a potential model of PD and showed moderate, but progressive loss of nigrostriatal neurons and motor impairment [66]. VMAT2 deficiency resulted in significant depletion of NA and 5-HT levels, allowing broad investigations on the role of monoamines in the generation of non-motor symptoms in PD. The recent article by Taylor and coauthors demonstrates that, indeed, VMAT2-deficient mice exhibit an age-dependent phenotype mimicking many of the non-motor symptoms of PD [67]. Of particular relevance, VMAT2-deficient mice displayed a clear age-dependent depressive-like phenotype as only old (12-15 months), but not young (4-6 months), mice showed a significant increase in immobility time in the FST and TST [67]. Likewise, VMAT2-heterozygote (HET) mice, with a $42 \%$ DA deficiency in the striatum compared to WT [68], showed a depressive-like phenotype with increased immobility time in the TST and FST, decreased sucrose consumption and a robust increase in LH. However, no difference in the NSF test was found when comparing WT and VMAT2-HET mice, but this test has a high anxiety-like component [69].

\section{NEURONAL CIRCUITRIES INVOLVED IN DEPRESSION AND PD}

Basal ganglia are a group of interconnected nuclei (SNc, SN reticulata, striatum, globus pallidus, entopeduncular nucleus and subthalamic nucleus) that connect with different parts of the cerebral cortex and thalamus. The pathological changes in these areas in 
relation to motor symptoms of PD have been extensively investigated [e.g. 70, 71]. However, some studies have also examined their role in non-motor functions [72]. Moreover, although PD is mainly known to be a disorder associated with the nigrostriatal DA cell loss, dysfunctions of additional neurotransmitter systems also participate in the symptomatology of PD, not least in non-motor symptoms. Interactions between 5-HT, NA and DA have been strongly implicated in reward-related behaviors and depression [73]. According to the Braak staging of PD pathology, NA and 5-HT dysfunctions occur prior to significant degradation of DA neurons [4, 74]. It is also well known that the activities of DA neurons in the $\mathrm{SNc}$ and of dopaminoceptive GABAergic neurons in the striatum are regulated by glutamate and modulated by acetylcholine and adenosine in the processing of proper movements [75, 76]. As discussed below, all these neurotransmitters may also play an important role in the pathophysiology of parkinsonian depression and represent targets for future treatments. It should also be emphasized that these neurotransmitters are abundant in several neuronal circuitries outside the basal ganglia, such as nucleus accumbens, hippocampus, amygdala and frontal cortex, which are implicated in depression and somewhat affected in PD.

\section{ROLE OF NEUROTRANSMITTERS IN DEPRESSION AND PD - FOCUS ON DATA FROM ANIMAL STUDIES}

\section{Dopamine}

DA has been extensively linked to the development and treatment of affective behaviors in the general population and in experimental models of depression [77, 78]. Clinical studies have established an association between decreased binding of the DA transporter in the ventral striatum and depressive symptoms in human [79].

The role of DA in depression has been extensively studied also in several animal models. For example, the effect of TCAs in rats was found to be related to the increased level of extracellular DA in the nucleus accumbens and prefrontal cortex after strong inhibition of the DA uptake [80]. Chronic antidepressants have been shown to produce sensitization of behavioral response to drugs acting on $\mathrm{D}_{2} / \mathrm{D}_{3}$ receptors in the nucleus accumbens [81]. Furthermore, anhedonic animals seem to respond with locomotor sensitization both to $\mathrm{D}_{2} / \mathrm{D}_{3}$ agonists and antidepressant drugs [82].
If diminished DA levels by themselves are leading to depression in PD, DA replacement therapy with L-DOPA should reduce depression. However, DAdepleted rats have been shown to express enhanced LH behavior, an effect that is only partially counteracted by L-DOPA [37]. In a recent study conducted in 6-OHDA lesioned rats, L-DOPA was shown to induce supraphysiological release of DA in prefrontal cortex and hippocampus [83]. The excessive efflux of DA in these areas could underlie the relatively low antidepressant efficacy of L-DOPA since it might cause agitation and psychosis. On the other hand, drugs such as the clinically used antidepressant bupropion, that inhibit DA reuptake, counteract the depressive-like behaviors of VMAT2-HET mice in the TST [69]. The effect of specific DA agonists has been also studied. Their different receptor specificity seems to possibly influence their effectiveness [84]. Whereas $\mathrm{D}_{2}$ receptors in the nigrostriatal pathway are mainly involved in modulation of motor functions, $\mathrm{D}_{3}$ receptors in the mesolimbic dopaminergic system appear to be more involved in the regulation of mood and behavior. The preferential stimulation of $\mathrm{D}_{3}$ receptors may explain antidepressant and anti-anhedonic properties of DA agonists like ropinirole and pramipexole. In binding studies, pramipexole exerted the greatest $\mathrm{D}_{3}$ versus $\mathrm{D}_{2}$ preference compared to other currently available DA agonists used for the treatment of PD [85]. In various animal models, pramipexole have antidepressant $[86,87]$ and hedonic effects [82].

It is important to note that evaluation of antidepressant effects of dopaminomimetics in animal models of PD is extremely challenging. For example, hemiparkinsonian rodents treated with dopaminergic drugs show turning behavior that can disturb the performance in the depression-like test. Furthermore, administration of dopaminergic compounds such as L-DOPA, especially if given chronically, can cause dyskinetic movements and these repetitive and purposeless behaviors can also influence a good test execution.

\section{Noradrenaline}

Noradrenergic neurons are degenerated in the locus coeruleus of PD patients prior to nigral DA neurons degeneration [4]. Lower level of DA/NA transporter in the locus coeruleus seems to correlate with an increase of incidence for depression [79]. Accordingly, a recent positron emission tomography study in humans, showed that binding of $\left[{ }^{11} \mathrm{C}\right] \mathrm{RTI}-32$ in brain regions that receive noradrenergic innervations was significantly lower in depressed patients with PD 
when compared to non-depressed patients with PD [79]. NA levels have not been much studied in animal models of depression in PD and results are very contradictory. Increased level of NA was shown in the prefrontal cortex and hippocampus of 6-OHDA lesioned rats while no significant difference was found in rats intracranially injected with other neurotoxins, such as MPTP, rotenone or LPS $[31,36]$. In the depressive-like VMAT2-deficent mice, a strong decrease of both DA and NA was observed in the striatum, cortex and hippocampus [67]. Furthermore, the increased immobility in the TST found in this model has been shown to be reduced in mice treated with the NA reuptake inhibitors, reboxetine or desipramine [67, 69].

\section{Serotonin}

The role of 5-HT in depression in PD is still not clear. In a recent study, neuronal loss and gliosis was observed in the SNc and locus coeruleus but not in the raphe nuclei of PD patients with depression [88]. In contrast, others studies have found increased pathology in the raphe nuclei of depressed compared to nondepressed PD patients $[89,90]$. Moreover, levels of 5-hydroxyindoleaceticacid (5-HIAA, a 5-HT metabolite) have been shown to be lower in the cerebrospinal fluid of depressed PD patients in several [91, 92], but not all [93] studies.

In animals, lesion of dopaminergic system with 6-OHDA or MPTP causes changes in the 5-HT system. Interestingly, this effect depends on several factors like age, toxin used and protocol of lesion. Some studies showed no 5-HT system impairment after MPTP treatment [94] but others found a significant depletion of 5-HT following MPTP lesion in mouse [44, 95]. On the other hand, no correlation was found between the decrease in 5-HT with a depressivelike phenotype. In contrast, in a rat study where comparisons were made of several neurotoxins, the degree of lesioning of the 5-HT and DA systems correlated significantly with swimming or immobility in the FST [36]. A more detailed analysis revealed that neurotoxin-mediated reductions in DA correlated well with increased immobility, whereas neurotoxinmediated lowering of 5-HT levels correlated better with a decrease in the swimming parameters [36]. Studies performed in the 6-OHDA model showed that imipramine could improve depression-like behavior in the FST [96]. It is noteworthy that L-DOPA has been shown to affect 5-HT and NA levels in several areas of the brain, such as prefrontal cortex, amygdala and hip- pocampus, and these effects have been seen in intact rats [97] as well as DA-depleted animals [98, 99]. LDOPA treatment can indeed, via decarboxylation and beta-hydroxylation, form NA and, via decarboxylation in 5-HT neurons, form "false DA" that displaces and lowers 5-HT. An inhibition of the 5-HT system in "emotional" regions suggests that L-DOPA treatment might even promote the development of affective symptoms.

$5-\mathrm{HT}_{1 \mathrm{~A}}$ receptors are important in the regulation of mood and emotionality and are thought to mediate some therapeutic actions of antidepressants including SSRIs [100]. SSRIs, TCAs, and electroconvulsive shock therapy increase post-synaptic $5-\mathrm{HT}_{1 \mathrm{~A}}$ receptor signaling through direct or indirect effects [100]. Sarizotan has high affinities to $5-\mathrm{HT}_{1 \mathrm{~A}}$ receptors and DA $\mathrm{D}_{4}>\mathrm{D}_{3}>\mathrm{D}_{2}$ receptors, with the profile of a $5-\mathrm{HT}_{1 \mathrm{~A}}$ receptor agonist and $\mathrm{D}_{2}$-like receptor partial agonist [101]. It was recently found that sarizotan significantly reduced the immobility in the FST of unilaterally 6OHDA lesioned rats [35].

\section{Amino acids - glutamate and GABA}

Glutamate is the major excitatory neurotransmitter in the brain and acts via multiple metabotropic and ionotropic receptors. Recent findings indicate that levels of glutamate are reduced in the anterior cingulate cortex of depressed subjects $[102,103]$ while these levels are normalized upon successful antidepressant treatment [104]. Glutamate has a direct modulatory function of the 5-HT system [105] and vice-versa. Chronic, but not acute, treatment with a variety of monoamine-based antidepressants leads to an increase in the phosphorylation state of synaptic AMPA and a down-regulation of NMDA glutamate receptor levels [106]. In clinical trials, the glutamate NMDA receptor antagonist, ketamine, exerted a rapid and sustained antidepressant effect in formerly treatment resistant patients [107]. In pre-clinical studies, ketamine reduced the immobility time in the TST for $72 \mathrm{~h}$ [108]. Moreover, acute administration of ketamine decreased the number of escape failures in the $\mathrm{LH}$ paradigm in rats and this rapid response was related to the synthesis of the brain derived neurotrophic factor (BDNF) [109]. Since there are major dysfunctions in corticostriatal glutamatergic transmission in $\mathrm{PD}$, it is possible that modulation of glutamatergic transmission may exert antidepressant properties also in PD patients. At the moment, no studies have examined antidepressant effects of glutamate compounds in PD models. 
Another amino acid, GABA, is the predominant inhibitory neurotransmitter of the brain. Accumulating evidence over the past years indicate that also GABA transmission is critically altered in depression with changes in several different neuronal circuitries [110] and antidepressant treatments, such as SSRIs and TCAs, have effect on GABAergic neurotransmission [111]. Pre-clinical studies showed a depressive-like phenotype in mouse lines with deficit in the expression of different subtypes of the $\mathrm{GABA}_{\mathrm{A}}$ receptor, including HET mice for the gamma subunit $[112,113]$ and KO mice for the delta subunit [114]. So far, the role of GABA transmission in depression in PD has not been evaluated in human or animal models.

\section{Acetylcholine}

Manipulation of acetylcholine receptors play an important role in emotional states including depression [115]. Scopolamine, a muscarinic receptor antagonist, exhibits antidepressant properties in depressed patients [116] and animal data also suggest a role for muscarinic receptors in depression. For example, the Flinders Sensitive rat line of depression is bred for increased sensitivity of muscarinic receptors and exhibits increases in response to cholinomimetic drugs in the FST [117].

Effects of acetylcholine on mood also involve nicotine receptors [118]. In an animal model of depression, nicotine receptor antagonists, especially mecamylamine, showed antidepressant properties [119, 120], and this effect was lost in mice lacking $\alpha 7$ or $\beta 2$ receptor subunits [121]. Paradoxically, nicotinic receptor agonists, e.g. cytisine, sazetidine-A or varenicline, also showed antidepressant-like properties in mice [120, 122-124]. Similarly, acute and chronic nicotine reduced immobility time in the FST in the Flinders Sensitive Line of rats [125].

Anticholinergic agents have been used for many years in the treatment of PD and are especially beneficial against parkinsonian tremor [126]. Interestingly, a recent clinical finding provided evidences for the role of cholinergic neurotransmission in parkinsonian depression showing that reduced $\alpha 4 \beta 2 *$-nAChR binding in patients with PD within subcortical and cortical regions was associated with the severity of depressive symptoms [127].

\section{Adenosine}

Adenosine has an important modulatory role in the central nervous system. Low concentration of adenosine is physiologically present in the extracellular fluid while it increases exponentially under pathological conditions [128]. Among the four distinct receptors $\left(\mathrm{A}_{1}, \mathrm{~A}_{2 \mathrm{~A}}, \mathrm{~A}_{2 \mathrm{~B}}\right.$, and $\left.\mathrm{A}_{3}\right), \mathrm{A}_{1}$ receptors are widely abundant in the brain, especially in the cortex, while $\mathrm{A}_{2 \mathrm{~A}}$ receptors are located mainly in the striatum [128, 129]. The strong anatomical and functional interaction between $A_{2 A}$ and $D_{2}$ receptors in the indirect striatopallidal GABAergic pathway [130] led to the important finding that $\mathrm{A}_{2 \mathrm{~A}}$ receptors antagonists can significantly improve motor dysfunctions in PD [131-133]. Subsequently, antagonism of $\mathrm{A}_{2 \mathrm{~A}}$ receptors has also been shown to have neuroprotective effect in the MPTP and 6-OHDA models of PD [134, 135].

Interestingly, modulation of the adenosine system tends to produce depressant-like effects in animal models. Stimulation of adenosine receptors induces a state of LH similar to that observed in animal models of depression [136, 137] and increases the immobility time in the FST with antidepressants reversing this effect [138]. Moreover, adenosine $\mathrm{A}_{2 \mathrm{~A}}$ antagonists have antidepressant like properties in several animal paradigms [139, 140].

\section{ROLE OF STEROIDS IN DEPRESSION AND PD}

Stress is a common environmental trigger of depression and a crucial component in human depression is a dysfunctional HPA (hypothalamic-pituitary-adrenal) axis [141, 142]. In major depressive disorder, an excessive activation of this circuit has been found in almost 50\% of depressed individuals [143, 144]. Depressed patients, as well as patients with Cushing's disease, have reduced hippocampal volume [141, 142]. Corticosteroids may cause this effect via several mechanisms including reduced neurogenesis and shrinkage of the dendritic tree of hippocampal neurons [142]. In line with these findings, glucocorticoid and corticotropin-releasing factor receptor antagonists are currently being tested as antidepressants in clinical trials. However, it should be emphasized that atypical forms of depression, such as "burnout", are accompanied by hypocortisolemia [141, 142]. It is likely that changes in the HPA axis are involved in parkinsonian depression, but it remains largely neglected both in patient and animal studies.

Depression and depression-related diseases are more common in females than males, both in a normal population and among PD patients, suggesting an important involvement of gonadal steroids [145]. Since particular depressive states, such as post partum 
depression, seem to follow body concentration of progesterone and estrogen that dramatically drops after the delivery, several models of hormonal withdrawal have been developed in animals and all of them have been associated with depressive-like behaviors [146, 147]. Interestingly, progesterone has been showed to prevent depressive-like FST behavior in parkinsonian animals [96].

Neurosteroids are synthesized or metabolized in the brain and can affect neuronal functions. Decreased levels of pregnenolone, the most abundant steroid in the CNS, were found in depressed individuals [148]. Moreover, the administration of this steroid to rodents was able to decrease the immobility time in the FST [149]. The importance of pregnenolone for effects of antidepressant drugs was suggested when increased levels were found in the cerebral cortex and hippocampus of imipramine-treated rats [150, 151]. A similar compound, allopregnenolone, was also shown to have a link with depression in human and animal studies $[152,153]$. At the moment, there are no studies on the role of neurosteroids in parkinsonian depression.

\section{ROLE OF NEUROTROPHIC FACTORS IN DEPRESSION AND PD}

\section{Brain-derived neurotrophic factor}

BDNF is the most abundant neurotrophin expressed in the brain [154]. It promotes neuronal survival and differentiation and modulates synaptic plasticity through the receptor tyrosine kinase (Trk) B [155].

Post mortem studies showed that BDNF levels are reduced in the $\mathrm{SNc}$ of parkinsonian brain [156-158] and this decrease seems to be a result of reduced transcription of the BDNF gene. It has also been demonstrated that pathogenic mutations of $\alpha$-synuclein, associated with early-onset familiar PD are linked to decreased BDNF production [159].

Moreover, several animal studies evaluated the link between decreased BDNF and PD. The infusion of antisense BDNF oligonucleotides into rat SNc generated animals that exhibit some characteristics of the classical models of PD [160]. Animals completely lacking BDNF in the midbrain and in the hindbrain displayed a persistent reduction of DA in the SNc [161]. Moreover, mice expressing only half of the normal levels of BDNF were shown to have a compromised striatal DA output and impaired behavioral response [162]. Recently, TrkB hypomorphic mutants showed late-onset DA neuronal loss that is confined in the $\mathrm{SNc}$ and does not appear until 12 months of age [163].
Accordingly, the delivery of BDNF in experimental animal models of PD rescued degenerating DA neurons in the SNc [164]. Intrastriatal grafts of fibroblasts, genetically modified to produce BDNF, were used to prevent the 6-OHDA-induced loss of neurons in rats [165] while cell-mediated delivery of BDNF increased DA levels in the MPTP model of PD [166]. Furthermore, nigral infusion of BDNF in mice partially reversed MPTP-induced DA decrease.

There are clear links between BDNF and depression. In fact, depressed patients showed a reduction in hippocampal [167] and serum BDNF level [168] and several antidepressant drugs, given chronically, cause a normalization. There is also evidence that BDNF can regulate functions relevant to antidepressant-response in rats. Chronic infusion of BDNF into posterior midbrain nuclei resulted in effects that are similar to those of antidepressants in FST and LH [169]. Furthermore, administration of BDNF directly into localized regions of the hippocampus similarly resulted in antidepressant properties in these behavioral models [170]. No studies on the role of BDNF in depressive behaviors have been performed in PD models.

\section{Vascular endothelial growth factor (VEGF)}

VEGF plays an important role in depression and in mediating the effect of common antidepressant treatments. Intracranial infusion of VEGF in animals showed antidepressant properties in depression-like paradigms, such LH, FST and NSF [171]. Interestingly, infusion of the VEGF inhibitor, SU5416, blocked the behavioral effect of desipramine and fluoxetine $[171,172]$.

Moreover, VEGF has also been studied for its beneficial effect on neurons and reduced level of VEGF can induce neurodegeneration by impairing vasoregulation, neural tissue perfusion, and normal functioning of perivascular autonomic nerves. VEGF gene transfer, mediated by adeno-associated virus, has been shown to promote dopaminergic neuronal survival in 6-OHDA lesioned rats [173]. VEGF levels are increased upon L-DOPA treatment in PD models [174]. It would therefore be interesting to study whether VEGF could exert also antidepressant properties in PD models.

\section{ADULT NEUROGENESIS IN DEPRESSION AND PD}

Newborn neurons are produced in the adult brain in rodents as well as humans [175]. Although neurogenesis in adult is much less frequent than in 
embryonic development, several thousand new granule neurons are generated every day [176]. Neurogenesis occurs in two different areas of the brain: the neurons that are born in the subventricular zone (SVZ) of the lateral ventricle migrate into the olfactory bulb $(\mathrm{OB})$ and become interneurons while the neurons born in the subgranular zone (SGZ) of the dentate gyrus (DG) migrate to the granular layer of the DG to eventually become mature granule neurons.

Early studies showed that various antidepressant regimens to rodents increase cell proliferation and neurogenesis in the SGZ [141] and a "neurogenic theory" postulated a link between decreased rate of neurogenesis in the SGZ with the vulnerability for depression. However, more recent work has shown that attenuated neurogenesis per se is not enough to carry a depression-like phenotype. When studying neurogenesis in rodents, the strain is of critical importance due to varying levels of proliferation and neurogenic response between strains as well as response to stress [177-179].

Interestingly, alterations in neurogenesis have also been observed in PD. The number of proliferating cells in the SVZ of the striatum and in the SGZ of the DG were reported to be reduced in post-mortem brains of individuals with $\mathrm{PD}$ and restored by treatment with L-DOPA or selective agonists for $\mathrm{D}_{2}$ receptors [178]. Decreased cell proliferation was also found in several experimental PD models, such as 6-OHDAlesioned rats, MPTP-injected mice and monkeys and in the transgenic mouse model expressing human $\alpha$ synuclein [178, 180-182]. An altered neurogenesis has also been observed in various-synuclein overexpressing models of PD with reduced proliferation in both the DG [182-184] and SVZ/OB systems [185]. However, recent studies showed that the proliferative capacity in the SVZ of MPTP-treated animals and aphakia mice is not affected while mice with depletion of dopaminergic neurons in the ventrolateral VTA have impaired SVZ proliferation [186, 187]. Two frequently used DA agonists (ropinirole and pramipexole) showed a regenerative effect on SVZ proliferation in PD models [178, 188]. Likewise, sarizotan also increased cell proliferation in the SVZ and SGZ especially in the 6OHDA-lesioned hemisphere [35] and, as mentioned above, sarizotan has affinity for serotonin $5-\mathrm{HT}_{1 \mathrm{~A}}$ receptors that are known to regulate neurogenesis in the SGZ. Indeed, 5- $\mathrm{HT}_{1 \mathrm{~A}}$ receptor $\mathrm{KO}$ mice have been shown to be insensitive to the neurogenic effects of fluoxetine in the SGZ [189]. In accordance, selective antagonism at 5- $\mathrm{HT}_{1 \mathrm{~A}}$ receptors decreased cell proliferation in the SGZ [190] and, vice versa, stimulation of $5-\mathrm{HT}_{1 \mathrm{~A}}$ receptors increased cell proliferation in this region [191].

\section{INFLAMMATION IN DEPRESSION AND PD}

In both patients and experimental models of PD, neuroinflammation appears to be an ubiquitous finding together with phagocyte activation, increased synthesis and release of proinflammatory cytokines and complement activation. In particular, activation of microglial cells has been found in several paradigms of PD such as the MPTP [10], rotenone [192] and 6-OHDA [193] models. LPS-induced microglial activation seems to induce neurodegeneration of DA neurons in the SNc [194-196]. More recent studies clearly indicate that inflammatory cytokines as TNF- $\alpha$ or IL- 6 are toxic to neurons [197, 198]. Furthermore, genetic inactivation of COX-2 or TNF- $\alpha$ receptors has been shown to protect DA neurons against MPTP-induced neurotoxicity [198, 199]. Likewise non-steroidal anti-inflammatory drugs have been shown to be potential agents against neurodegeneration in animal models of PD [200, 201]. Moreover, minocycline, that decreases the production of several pro-inflammatory molecules, was shown to have neuroprotective effect on DA neurons in MPTP, LPS and 6-OHDA animal models of PD [202-205].

Interestingly, various clinical and pre-clinical findings suggest that depression is associated with an increased production of pro-inflammatory cytokines [206-210]. Cytokine administration or systemic administration of LPS induced depression-like symptoms in animal models of depression [211-213]. Indeed, recent studies showed that systemic LPS administration increased immobility in both FST and TST in mice [214, 215]. Furthermore, the effect of acute and repeated administration of LPS was studied in the ICSS paradigm. Compared to vehicle-treated animals, acute exposure to LPS induced a dramatic loss of ICSS responding; however, with repeated exposure to LPS, rats developed a behavioral tolerance to its anhedonic effects [216]. It has also been shown that LPS has an altered response in the OB model of depression with $\mathrm{OB}$ animals displaying a blunted increase in 5-HIAA in the nucleus accumbens compared with control animals. The resistance to LPS-induced activation of accumbal serotonergic activity may be due to impaired secretion of proinflammatory cytokines in response to LPS in the OB animals [217]. To further link inflammation to depression, studies have shown that antidepressants attenuate inflammation-induced 


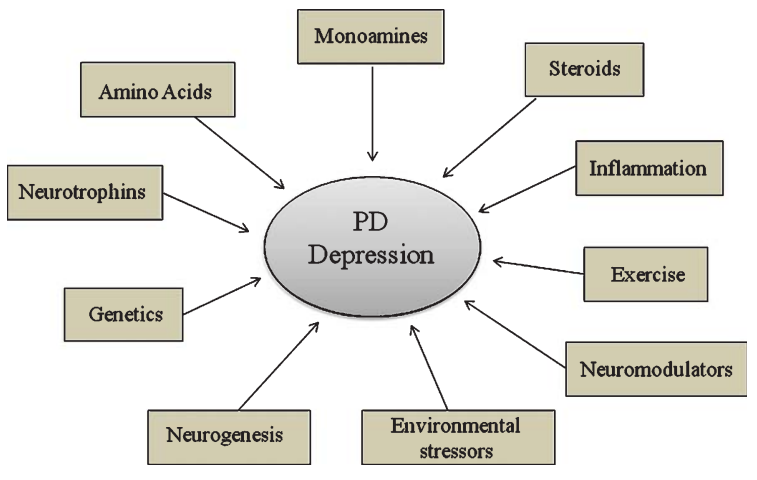

Fig. 1. Summary of different systems which could underlie depressive symptomatology in PD and have been studied in animal models.

cytokines production and action in the brain, which is associated with the reduction of depressive-like symptoms [218, 219]. In parallel, subchronic treatment with IL-1 was found to both reduce BDNF expression at both protein and mRNA levels and down regulate the TrkB receptor expression in the hippocampus [220]. Moreover, inflammation and cytokine expression have been shown to inhibit neurogenesis [221, 222] while immunomodulators have a concentrationdependent pro-neurogenic potential in the adult brain [223]. At the moment, no studies have examined the role of inflammation in animal models of parkinsonian depression.

\section{REGULATION OF PD AND DEPRESSION BY DEEP BRAIN STIMULATION}

Almost 100.000 PD patients have undergone deep brain stimulation (DBS) surgery, mostly targeting the subthalamic nucleus [224]. While beneficial against the motor symptoms of PD, it has become apparent that individuals who receive the treatment have an increased risk of suicide [225]. Studies in animal models of PD have demonstrated that subthalamic nucleus stimulation reduces the activity of the 5-HT system which could participate in the depression symptomatology [226]. In contrast, recent studies have demonstrated that DBS of the subgenual cingulate cortex [227] and the nucleus accumbens [228] can successfully alleviate depressive symptoms in nonPD patients with major depression that is refractory to medical treatments. Future animal studies may facilitate the identification of brain regions which upon DBS relieve both PD and depression.

\section{EXERCISE AS TREATMENT OPTION IN DEPRESSION AND PD}

Recent studies have demonstrated that exercise improves motor function in animal models of PD [229-231] or neuropsychiatric symptoms in normal mice [232]. The MPTP mouse model has been used to assess the potential positive effect of exercise on symptoms of depression in PD [233]. Unexpectedly, this study did not show any improvement in the sucrose preference test and in the TST [233]. Thus, it seems difficult to properly judge the effect of exercise on depression using the MPTP model.

\section{CONCLUSIONS}

Depression is a common non-motor symptom of PD. Despite the impact of depression on quality of life for PD patients, there is not much research done in animal models. Many tests of depression-like behavior in animals rely on locomotion and are not ideal for studies in PD models. However, some tests, including sucrose preference and $\mathrm{NIH}$, are largely independent upon locomotion and can provide reliable data when studying a depressive-like phenotype in a PD model. There is also a need for the development of additional motor independent depression-related tests for animal models of PD. Since depression often is an early sign of PD, many acute models, such as the 6-OHDA model, are not ideal for depression-related studies. More progressive models of PD pathology have better construct validity and impressive studies on non-motor symptomatology have been performed using VMAT2 mutant mice. Changed in limbic DA, NA and perhaps 5-HT are involved in parkinsonian depression, but future work will probably also find important roles for additional factors, like amino acids and neurotrophins, and processes, like stress and inflammation.

\section{ACKNOWLEDGMENTS}

This work was supported by the Swedish Research Council, Swedish Strategic Research Fund and Swedish Brain Fund.

\section{REFERENCES}

[1] Bower JH, Maraganore DM, McDonnell SK, \& Rocca WA (1999) Incidence and distribution of parkinsonism in Olmsted County, Minnesota, 1976-1990. Neurology, 52, 1214-1220. 
[2] Brooks SP, \& Dunnett SB (2009) Tests to assess motor phenotype in mice: A user's guide. Nat Rev Neurosci, 10, 519-529.

[3] Meredith GE, \& Kang UJ (2006) Behavioral models of Parkinson's disease in rodents: A new look at an old problem. Mov Disord, 21, 1595-1606.

[4] Braak H, Del Tredici K, Rub U, de Vos RA, Jansen Steur EN, \& Braak E (2003) Staging of brain pathology related to sporadic Parkinson's disease. Neurobiol Aging, 24, 197-211.

[5] Aarsland D, Påhlhagen S, Ballard CG, Ehrt U, \& Svenningsson P (2012) Depression in Parkinson diseaseepidemiology, mechanisms and management. Nat Rev Neurol, 8(1), 35-47.

[6] Shiba M, Bower JH, Maraganore DM, McDonnell SK, Peterson BJ, Ahlskog JE, Schaid DJ, \& Rocca WA (2000) Anxiety disorders and depressive disorders preceding Parkinson's disease: A case-control study. Mov Disord, 15, 669-677.

[7] Cummings JL (1992) Depression and Parkinson's disease: A review. Am J Psychiatry, 149, 443-454.

[8] Klein A, Metz GA, Papazoglou A, \& Nikkhah G (2007) Differential effects on forelimb grasping behavior induced by fetal dopaminergic grafts in hemiparkinsonian rats. Neurobiol Dis, 27, 24-35.

[9] Pinna A, Pontis S, Borsini F, \& Morelli M (2007) Adenosine $\mathrm{A} 2 \mathrm{~A}$ receptor antagonists improve deficits in initiation of movement and sensory motor integration in the unilateral 6-hydroxydopamine rat model of Parkinson's disease. Synapse, 61, 606-614.

[10] Schintu N, Frau L, Ibba M, Garau A, Carboni E, \& Carta AR (2009) Progressive dopaminergic degeneration in the chronic MPTPp mouse model of Parkinson's disease. Neurotox Res, 16, 127-139.

[11] Nestler EJ, \& Hyman SE (2010) Animal models of neuropsychiatric disorders. Nat Neurosci, 13, 1161-1169.

[12] Porsolt RD, Le Pichon M, \& Jalfre M (1977) Depression: A new animal model sensitive to antidepressant treatments. Nature, 266, 730-732.

[13] Pollak DD, Rey CE, \& Monje FJ (2010) Rodent models in depression research: Classical strategies and new directions. Ann Med, 42, 252-264.

[14] Pollak DD, Monje FJ, Zuckerman L, Denny CA, Drew MR, \& Kandel ER (2008) An animal model of a behavioral intervention for depression. Neuron, 60, 149-161.

[15] Detke MJ, Rickels M, \& Lucki I (1995) Active behaviors in the rat forced swimming test differentially produced by serotonergic and noradrenergic antidepressants. Psychopharmacology (Berl), 121, 66-72.

[16] Steru L, Chermat R, Thierry B, \& Simon P (1985) The tail suspension test: A new method for screening antidepressants in mice. Psychopharmacology (Berl), 85, 367-370

[17] Cryan JF, Markou A, \& Lucki I (2002) Assessing antidepressant activity in rodents: Recent developments and future needs. Trends Pharmacol Sci, 23, 238-245.

[18] Liu X, \& Gershenfeld HK (2001) Genetic differences in the tail-suspension test and its relationship to imipramine response among 11 inbred strains of mice. Biol Psychiatry, 49, 575-581.

[19] Dulawa SC, Holick KA, Gundersen B, \& Hen R (2004) Effects of chronic fluoxetine in animal models of anxiety and depression. Neuropsychopharmacology, 29, 1321-1330.

[20] Dulawa SC, \& Hen R (2005) Recent advances in animal models of chronic antidepressant effects: The noveltyinduced hypophagia test. Neurosci Biobehav Rev, 29, $771-783$.
[21] Reus V (2008) Mental disorders. In Harrison's Principles of Internal Medicine (Fauci, A., ed), McGraw-Hill Medical, pp. 2710-2723.

[22] Jayatissa MN, Bisgaard C, Tingstrom A, Papp M, \& Wiborg O (2006) Hippocampal cytogenesis correlates to escitalopram-mediated recovery in a chronic mild stress rat model of depression. Neuropsychopharmacology, 31, 23952404.

[23] Slattery DA, Markou A, \& Cryan JF (2007) Evaluation of reward processes in an animal model of depression. Psychopharmacology (Berl), 190, 555-568.

[24] Moreau JL, Jenck F, Martin JR, Mortas P, \& Haefely WE (1992) Antidepressant treatment prevents chronic unpredictable mild stress-induced anhedonia as assessed by ventral tegmentum self-stimulation behavior in rats. Eur Neuropsychopharmacol, 2, 43-49.

[25] Sherman AD, Sacquitne JL, \& Petty F (1982) Specificity of the learned helplessness model of depression. Pharmacol Biochem Behav, 16, 449-454.

[26] Willner P (2005) Chronic mild stress (CMS) revisited: Consistency and behavioural-neurobiological concordance in the effects of CMS. Neuropsychobiology, 52, 90-110.

[27] Berton O, McClung CA, Dileone RJ, Krishnan V, Renthal W, Russo SJ, Graham D, Tsankova NM, Bolanos CA, Rios M, Monteggia LM, Self DW, \& Nestler EJ (2006) Essential role of BDNF in the mesolimbic dopamine pathway in social defeat stress. Science, 311, 864-868.

[28] Krishnan V, Han MH, Graham DL, Berton O, Renthal W, Russo SJ, Laplant Q, Graham A, Lutter M, Lagace DC, Ghose S, Reister R, Tannous P, Green TA, Neve RL, Chakravarty S, Kumar A, Eisch AJ, Self DW, Lee FS, Tamminga CA, Cooper DC, Gershenfeld HK, \& Nestler EJ (2007) Molecular adaptations underlying susceptibility and resistance to social defeat in brain reward regions. Cell, 131, 391-404.

[29] Song C, \& Leonard BE (2005) The olfactory bulbectomised rat as a model of depression. Neurosci Biobehav Rev, 29, 627-647.

[30] Ungerstedt U (1968) 6-Hydroxy-dopamine induced degeneration of central monoamine neurons. Eur J Pharmacol, 5, 107-110.

[31] Tadaiesky MT, Dombrowski PA, Figueiredo CP, CargninFerreira E, Da Cunha C, \& Takahashi RN (2008) Emotional, cognitive and neurochemical alterations in a premotor stage model of Parkinson's disease. Neuroscience, 156, 830-840.

[32] Lee CS, Sauer H, \& Bjorklund A (1996) Dopaminergic neuronal degeneration and motor impairments following axon terminal lesion by instrastriatal 6-hydroxydopamine in the rat. Neuroscience, 72, 641-653.

[33] Branchi I, D'Andrea I, Armida M, Cassano T, Pezzola A, Potenza RL, Morgese MG, Popoli P, \& Alleva E (2008) Nonmotor symptoms in Parkinson's disease: Investigating early-phase onset of behavioral dysfunction in the 6-hydroxydopamine-lesioned rat model. J Neurosci Res, $\mathbf{8 6}$, 2050-2061.

[34] Eskow Jaunarajs KL, Angoa-Perez M, Kuhn DM, \& Bishop C (2011) Potential mechanisms underlying anxiety and depression in Parkinson's disease: Consequences of l-DOPA treatment. Neurosci Biobehav Rev, 35, 556-564.

[35] Zhang X, Egeland M, \& Svenningsson P (2011) Antidepressant-like properties of sarizotan in experimental Parkinsonism. Psychopharmacology (Berl), 218, 621-634.

[36] Santiago RM, Barbieiro J, Lima MM, Dombrowski PA, Andreatini R, \& Vital MA (2010) Depressive-like behaviors alterations induced by intranigral MPTP, 6-OHDA, LPS and 
rotenone models of Parkinson's disease are predominantly associated with serotonin and dopamine. Prog Neuropsychopharmacol Biol Psychiatry, 34, 1104-1114.

[37] Winter C, von Rumohr A, Mundt A, Petrus D, Klein J, Lee T, Morgenstern R, Kupsch A, \& Juckel G (2007) Lesions of dopaminergic neurons in the substantia nigra pars compacta and in the ventral tegmental area enhance depressive-like behavior in rats. Behav Brain Res, 184, 133-141.

[38] Dunnett SB, \& Lelos M (2010) Behavioral analysis of motor and non-motor symptoms in rodent models of Parkinson's disease. Prog Brain Res, 184, 35-51.

[39] Arai N, Misugi K, Goshima Y, \& Misu Y (1990) Evaluation of a 1-methyl-4-phenyl-1,2,3,6-tetrahydropyridine (MPTP)-treated C57 black mouse model for parkinsonism. Brain Res, 515, 57-63.

[40] Fredriksson A, Eriksson P, \& Archer T (1997) MPTPinduced deficits in motor activity: Neuroprotective effects of the spintrapping agent, alpha-phenyl-tert-butyl-nitrone (PBN). J Neural Transm, 104, 579-592.

[41] Willis GL, \& Donnan GA (1987) Histochemical, biochemical and behavioural consequences of MPTP treatment in C-57 black mice. Brain Res, 402, 269-274.

[42] Nishi K, Kondo T, \& Narabayashi H (1991) Destruction of norepinephrine terminals in 1-methyl-4-phenyl-1,2,3,6tetrahydropyridine (MPTP)-treated mice reduces locomotor activity induced by L-dopa. Neurosci Lett, 123, 244-247.

[43] Mori A, Ohashi S, Nakai M, Moriizumi T, \& Mitsumoto Y (2005) Neural mechanisms underlying motor dysfunction as detected by the tail suspension test in MPTP-treated C57BL/6 mice. Neurosci Res, 51, 265-274.

[44] Vuckovic MG, Wood RI, Holschneider DP, Abernathy A, Togasaki DM, Smith A, Petzinger GM, \& Jakowec MW (2008) Memory, mood, dopamine, and serotonin in the 1-methyl-4-phenyl-1,2,3,6-tetrahydropyridine-lesioned mouse model of basal ganglia injury. Neurobiol Dis, 32, 319-327.

[45] Petroske E, Meredith GE, Callen S, Totterdell S, \& Lau YS (2001) Mouse model of Parkinsonism: A comparison between subacute MPTP and chronic MPTP/probenecid treatment. Neuroscience, 106, 589-601.

[46] Fleming SM, Zhu C, Fernagut PO, Mehta A, DiCarlo CD, Seaman RL, \& Chesselet MF (2004) Behavioral and immunohistochemical effects of chronic intravenous and subcutaneous infusions of varying doses of rotenone. Exp Neurol, 187, 418-429.

[47] Klein A, Gidyk DC, Shriner AM, Colwell KL, Tatton NA, Tatton WG, \& Metz GA (2011) Dose-dependent loss of motor function after unilateral medial forebrain bundle rotenone lesion in rats: A cautionary note. Behav Brain Res, 222, 33-42.

[48] Menzaghi F, Whelan KT, Risbrough VB, Rao TS, \& Lloyd GK (1997) Interactions between a novel cholinergic ion channel agonist, SIB-1765F and L-DOPA in the reserpine model of Parkinson's disease in rats. J Pharmacol Exp Ther, 280, 393-401.

[49] Dawson L, Chadha A, Megalou M, \& Duty S (2000) The group II metabotropic glutamate receptor agonist, DCG-IV, alleviates akinesia following intranigral or intraventricular administration in the reserpine-treated rat. Br J Pharmacol, 129, 541-546.

[50] Carlsson A, Lindqvist M, \& Magnusson T (1957) 3,4-Dihydroxyphenylalanine and 5-hydroxytryptophan as reserpine antagonists. Nature, 180, 1200.

[51] Skalisz LL, Beijamini V, Joca SL, Vital MA, Da Cunha C, \& Andreatini R (2002) Evaluation of the face validity of reserpine administration as an animal model of depression-Parkinson's disease association. Prog Neuropsychopharmacol Biol Psychiatry, 26, 879-883.

[52] Bolandghamat S, Moghimi A, \& Iranshahi M (2011) Effects of ethanolic extract of pine needles (Pinus eldarica Medw.) on reserpine-induced depression-like behavior in male Wistar rats. Pharmacogn Mag, 7, 248-253.

[53] Corti O, Lesage S, \& Brice A (2011) What genetics tells us about the causes and mechanisms of Parkinson's disease. Physiol Rev, 91, 1161-1218.

[54] Polymeropoulos MH, Lavedan C, Leroy E, Ide SE, Dehejia A, Dutra A, Pike B, Root H, Rubenstein J, Boyer R, Stenroos ES, Chandrasekharappa S, Athanassiadou A, Papapetropoulos T, Johnson WG, Lazzarini AM, Duvoisin RC, Di Iorio G, Golbe LI, \& Nussbaum RL (1997) Mutation in the alpha-synuclein gene identified in families with Parkinson's disease. Science, 276, 2045-2047.

[55] Spillantini MG, Schmidt ML, Lee VM, Trojanowski JQ, Jakes R, \& Goedert M (1997) Alpha-synuclein in Lewy bodies. Nature, 388, 839-840.

[56] Chesselet MF (2008) In vivo alpha-synuclein overexpression in rodents: A useful model of Parkinson's disease? Exp Neurol, 209, 22-27.

[57] Oksman M, Tanila H, \& Yavich L (2006) Brain reward in the absence of alpha-synuclein. Neuroreport, 17, 11911194.

[58] Kirik D, Annett LE, Burger C, Muzyczka N, Mandel RJ, $\&$ Bjorklund A (2003) Nigrostriatal alpha-synucleinopathy induced by viral vector-mediated overexpression of human alpha-synuclein: A new primate model of Parkinson's disease. Proc Natl Acad Sci U S A, 100, 2884-2889.

[59] Goldberg MS, Fleming SM, Palacino JJ, Cepeda C, Lam HA, Bhatnagar A, Meloni EG, Wu N, Ackerson LC, Klapstein GJ, Gajendiran M, Roth BL, Chesselet MF, Maidment NT, Levine MS, \& Shen J (2003) Parkin-deficient mice exhibit nigrostriatal deficits but not loss of dopaminergic neurons. J Biol Chem, 278, 43628-43635.

[60] Itier JM, Ibanez P, Mena MA, Abbas N, Cohen-Salmon C, Bohme GA, Laville M, Pratt J, Corti O, Pradier L, Ret G, Joubert C, Periquet M, Araujo F, Negroni J, Casarejos MJ, Canals S, Solano R, Serrano A, Gallego E, Sanchez M, Denefle P, Benavides J, Tremp G, Rooney TA, Brice A, \& Garcia de Yebenes J (2003) Parkin gene inactivation alters behaviour and dopamine neurotransmission in the mouse. Hum Mol Genet, 12, 2277-2291.

[61] Palacino JJ, Sagi D, Goldberg MS, Krauss S, Motz C, Wacker M, Klose J, \& Shen J (2004) Mitochondrial dysfunction and oxidative damage in parkin-deficient mice. $J$ Biol Chem, 279, 18614-18622.

[62] Von Coelln R, Thomas B, Savitt JM, Lim KL, Sasaki M, Hess EJ, Dawson VL, \& Dawson TM (2004) Loss of locus coeruleus neurons and reduced startle in parkin null mice. Proc Natl Acad Sci U S A, 101, 10744-10749.

[63] Perez FA, \& Palmiter RD (2005) Parkin-deficient mice are not a robust model of parkinsonism. Proc Natl Acad Sci U S A, 102, 2174-2179.

[64] Li Y, Liu W, Oo TF, Wang L, Tang Y, Jackson-Lewis V, Zhou C, Geghman K, Bogdanov M, Przedborski S, Beal MF, Burke RE, \& Li C (2009) Mutant LRRK2(R1441G) BAC transgenic mice recapitulate cardinal features of Parkinson's disease. Nat Neurosci, 12, 826-828.

[65] Mooslehner KA, Chan PM, Xu W, Liu L, Smadja C, Humby T, Allen ND, Wilkinson LS, \& Emson PC (2001) Mice with very low expression of the vesicular monoamine transporter 2 gene survive into adulthood: Potential 
mouse model for parkinsonism. Mol Cell Biol, 21, 53215331.

[66] Caudle WM, Richardson JR, Wang MZ, Taylor TN, Guillot TS, McCormack AL, Colebrooke RE, Di Monte DA, Emson PC, \& Miller GW (2007) Reduced vesicular storage of dopamine causes progressive nigrostriatal neurodegeneration. J Neurosci, 27, 8138-8148.

[67] Taylor TN, Caudle WM, Shepherd KR, Noorian A, Jackson CR, Iuvone PM, Weinshenker D, Greene JG, \& Miller GW (2009) Nonmotor symptoms of Parkinson's disease revealed in an animal model with reduced monoamine storage capacity. J Neurosci, 29, 8103-8113.

[68] Fon EA, Pothos EN, Sun BC, Killeen N, Sulzer D, \& Edwards RH (1997) Vesicular transport regulates monoamine storage and release but is not essential for amphetamine action. Neuron, 19, 1271-1283.

[69] Fukui M, Rodriguiz RM, Zhou J, Jiang SX, Phillips LE, Caron MG, \& Wetsel WC (2007) Vmat2 heterozygous mutant mice display a depressive-like phenotype. J Neurosci, 27, 10520-10529.

[70] Galvan A, \& Wichmann T (2008) Pathophysiology of parkinsonism. Clin Neurophysiol, 119, 1459-1474.

[71] Halliday GM, Macdonald V, \& Henderson JM (2005) A comparison of degeneration in motor thalamus and cortex between progressive supranuclear palsy and Parkinson's disease. Brain, 128, 2272-2280.

[72] Calabresi P, De Murtas M, \& Bernardi G (1997) The neostriatum beyond the motor function: Experimental and clinical evidence. Neuroscience, 78, 39-60.

[73] Sasaki-Adams DM, \& Kelley AE (2001) Serotonindopamine interactions in the control of conditioned reinforcement and motor behavior. Neuropsychopharmacology, 25, 440-452.

[74] Del Tredici K, Rub U, De Vos RA, Bohl JR, \& Braak H (2002) Where does parkinson disease pathology begin in the brain? J Neuropathol Exp Neurol, 61, 413-426.

[75] Zhou FM, Wilson C, \& Dani JA (2003) Muscarinic and nicotinic cholinergic mechanisms in the mesostriatal dopamine systems. Neuroscientist, 9, 23-36.

[76] Roth RH, \& Elsworth JD (1995) Biochemical pharmacology of midbrain dopaminergic neurons. In The Forth Generation of progress (F. Bloom, D. Kupfer, eds.), Lippincott William \& Wilkins, New York, pp. 227-243.

[77] Chen Z, \& Skolnick P (2007) Triple uptake inhibitors: Therapeutic potential in depression and beyond. Expert Opin Investig Drugs, 16, 1365-1377.

[78] Dunlop BW, \& Nemeroff CB (2007) The role of dopamine in the pathophysiology of depression. Arch Gen Psychiatry, 64, 327-337.

[79] Remy P, Doder M, Lees A, Turjanski N, \& Brooks D (2005) Depression in Parkinson's disease: Loss of dopamine and noradrenaline innervation in the limbic system. Brain, 128, 1314-1322.

[80] Carboni E, Tanda GL, Frau R, \& Di Chiara G (1990) Blockade of the noradrenaline carrier increases extracellular dopamine concentrations in the prefrontal cortex: Evidence that dopamine is taken up in vivo by noradrenergic terminals. J Neurochem, 55, 1067-1070.

[81] Willner P (1997) The mesolimbic dopamine system as a target for rapid antidepressant action. Int Clin Psychopharmacol, 12(Suppl 3), S7-S14

[82] Willner P, Lappas S, Cheeta S, \& Muscat R (1994) Reversal of stress-induced anhedonia by the dopamine receptor agonist, pramipexole. Psychopharmacology (Berl), 115, 454-462.
[83] Navailles S, Benazzouz A, Bioulac B, Gross C, \& De Deurwaerdere P (2010) High-frequency stimulation of the subthalamic nucleus and L-3,4-dihydroxyphenylalanine inhibit in vivo serotonin release in the prefrontal cortex and hippocampus in a rat model of Parkinson's disease. J Neurosci, 30, 2356-2364.

84] Radad K, Gille G, \& Rausch WD (2005) Short review on dopamine agonists: Insight into clinical and research studies relevant to Parkinson's disease. Pharmacol Rep, 57, 701712.

[85] Piercey MF, Walker EL, Feldpausch DL, \& Camacho-Ochoa M (1996) High affinity binding for pramipexole, a dopamine D3 receptor ligand, in rat striatum. Neurosci Lett, 219, 138140.

[86] Maj J, RogozZ, Skuza G, \& Kolodziejczyk K (1997) Antidepressant effects of pramipexole, a novel dopamine receptor agonist. J Neural Transm, 104, 525-533.

[87] Breuer ME, Groenink L, Oosting RS, Buerger E, Korte M, Ferger B, \& Olivier B (2009) Antidepressant effects of pramipexole, a dopamine D3/D2 receptor agonist, and 7-OH-DPAT, a dopamine D3 receptor agonist, in olfactory bulbectomized rats. Eur J Pharmacol, 616, 134140.

[88] Frisina PG, Haroutunian V, \& Libow LS (2009) The neuropathological basis for depression in Parkinson's disease. Parkinsonism Relat Disord, 15, 144-148.

[89] Becker T, Becker G, Seufert J, Hofmann E, Lange KW, Naumann M, Lindner A, Reichmann H, Riederer P, Beckmann H, \& Reiners K (1997) Parkinson's disease and depression: Evidence for an alteration of the basal limbic system detected by transcranial sonography. J Neurol Neurosurg Psychiatry, 63, 590-596.

[90] Paulus W, \& Jellinger K (1991) The neuropathologic basis of different clinical subgroups of Parkinson's disease. J Neuropathol Exp Neurol, 50, 743-755.

[91] Mayeux R, Stern Y, Cote L, \& Williams JB (1984) Altered serotonin metabolism in depressed patients with parkinson's disease. Neurology, 34, 642-646.

[92] Kostic VS, Djuricic BM, Covickovic-Sternic N, Bumbasirevic L, Nikolic M, \& Mrsulja BB (1987) Depression and Parkinson's disease: Possible role of serotonergic mechanisms. J Neurol, 234, 94-96.

[93] Kuhn J, \& Huff W (2010) Will deep-brain stimulation be as successful in major depression as it has been in Parkinson's disease? Expert Rev Neurother, 10, 1363-1365.

[94] Sedelis M, Hofele K, Auburger GW, Morgan S, Huston JP, \& Schwarting RK (2000) MPTP susceptibility in the mouse: Behavioral, neurochemical, and histological analysis of gender and strain differences. Behav Genet, 30, 171-182.

[95] Rousselet E, Joubert C, Callebert J, Parain K, Tremblay L, Orieux G, Launay JM, Cohen-Salmon C, \& Hirsch EC (2003) Behavioral changes are not directly related to striatal monoamine levels, number of nigral neurons, or dose of parkinsonian toxin MPTP in mice. Neurobiol Dis, 14, 218-228.

[96] Casas S, Garcia S, Cabrera R, Nanfaro F, Escudero C, \& Yunes R (2011) Progesterone prevents depression-like behavior in a model of Parkinson's disease induced by 6-hydroxydopamine in male rats. Pharmacol Biochem Behav, 99, 614-618.

[97] Borah A, \& Mohanakumar KP (2007) Long-term L-DOPA treatment causes indiscriminate increase in dopamine levels at the cost of serotonin synthesis in discrete brain regions of rats. Cell Mol Neurobiol, 27, 985-996. 
[98] Maruyama W, Naoi M, Takahashi A, Watanabe H, Konagaya Y, Mokuno K, Hasegawa S, \& Nakahara D (1992) The mechanism of perturbation in monoamine metabolism by Ldopa therapy: In vivo and in vitro studies. J Neural Transm Gen Sect, 90, 183-197.

[99] Navailles S, Bioulac B, Gross C, \& De Deurwaerdere P (2010) Serotonergic neurons mediate ectopic release of dopamine induced by L-DOPA in a rat model of Parkinson's disease. Neurobiol Dis, 38, 136-143.

[100] Savitz J, Lucki I, \& Drevets WC (2009) 5-HT(1A) receptor function in major depressive disorder. Prog Neurobiol, 88 , 17-31.

[101] Bartoszyk GD, Van Amsterdam C, Greiner HE, Rautenberg W, Russ H, \& Seyfried CA (2004) Sarizotan, a serotonin 5-HT1A receptor agonist and dopamine receptor ligand. 1. Neurochemical profile. J Neural Transm, 111, 113126.

[102] Auer DP, Putz B, Kraft E, Lipinski B, Schill J, \& Holsboer F (2000) Reduced glutamate in the anterior cingulate cortex in depression: An in vivo proton magnetic resonance spectroscopy study. Biol Psychiatry, 47, 305-313.

[103] Hasler G, van der Veen JW, Tumonis T, Meyers N, Shen J, \& Drevets WC (2007) Reduced prefrontal glutamate/glutamine and gamma-aminobutyric acid levels in major depression determined using proton magnetic resonance spectroscopy. Arch Gen Psychiatry, 64, 193-200.

[104] Pfleiderer B, Michael N, Erfurth A, Ohrmann P, Hohmann U, Wolgast M, Fiebich M, Arolt V, \& Heindel W (2003) Effective electroconvulsive therapy reverses glutamate/glutamine deficit in the left anterior cingulum of unipolar depressed patients. Psychiatry Res, 122, 185-192.

[105] Soiza-Reilly M, \& Commons KG (2011) Glutamatergic drive of the dorsal raphe nucleus. J Chem Neuroanat, $\mathbf{4 1}$, 247-255.

[106] Sanacora G, Zarate CA, Krystal JH, \& Manji HK (2008) Targeting the glutamatergic system to develop novel, improved therapeutics for mood disorders. Nat Rev Drug Discov, 7, 426-437.

[107] Zarate CA Jr, Singh JB, Carlson PJ, Brutsche NE, Ameli R, Luckenbaugh DA, Charney DS, \& Manji HK (2006) A randomized trial of an N-methyl-D-aspartate antagonist in treatment-resistant major depression. Arch Gen Psychiatry, 63, 856-864.

[108] Koike H, Iijima M, \& Chaki S (2011) Involvement of AMPA receptor in both the rapid and sustained antidepressant-like effects of ketamine in animal models of depression. Behav Brain Res, 224, 107-111.

[109] Autry AE, Adachi M, Nosyreva E, Na ES, Los MF, Cheng PF, Kavalali ET, \& Monteggia LM (2011) NMDA receptor blockade at rest triggers rapid behavioural antidepressant responses. Nature, $\mathbf{4 7 5}, 91-95$.

[110] Luscher B, Shen Q, \& Sahir N (2011) The GABAergic deficit hypothesis of major depressive disorder. Mol Psychiatry, 16, 383-406.

[111] Kalueff AV, \& Nutt DJ (2007) Role of GABA in anxiety and depression. Depress Anxiety, 24, 495-517.

[112] Earnheart JC, Schweizer C, Crestani F, Iwasato T, Itohara S, Mohler H, \& Luscher B (2007) GABAergic control of adult hippocampal neurogenesis in relation to behavior indicative of trait anxiety and depression states. J Neurosci, 27, 38453854.

[113] Shen Q, Lal R, Luellen BA, Earnheart JC, Andrews AM, \& Luscher B (2010) gamma-Aminobutyric acid-type A receptor deficits cause hypothalamic-pituitary-adrenal axis hyperactivity and antidepressant drug sensitivity reminiscent of melancholic forms of depression. Biol Psychiatry, 68, 512-520.

[114] Maguire J, \& Mody I (2008) GABA(A)R plasticity during pregnancy: Relevance to postpartum depression. Neuron, 59, 207-213.

[115] Graef S, Schonknecht P, Sabri O, \& Hegerl U (2011) Cholinergic receptor subtypes and their role in cognition, emotion, and vigilance control: An overview of preclinical and clinical findings. Psychopharmacology (Berl), 215, 205-229.

[116] Furey ML, \& Drevets WC (2006) Antidepressant efficacy of the antimuscarinic drug scopolamine: A randomized, placebo-controlled clinical trial. Arch Gen Psychiatry, 63, 1121-1129.

[117] Overstreet DH, Friedman E, Mathe AA, \& Yadid G (2005) The Flinders Sensitive Line rat: A selectively bred putative animal model of depression. Neurosci Biobehav Rev, 29, 739-759.

[118] Drevets WC, \& Furey ML (2010) Replication of scopolamine's antidepressant efficacy in major depressive disorder: A randomized, placebo-controlled clinical trial. Biol Psychiatry, 67, 432-438.

[119] Caldarone BJ, Harrist A, Cleary MA, Beech RD, King SL, \& Picciotto MR (2004) High-affinity nicotinic acetylcholine receptors are required for antidepressant effects of amitriptyline on behavior and hippocampal cell proliferation. Biol Psychiatry, 56, 657-664.

[120] Mineur YS, Somenzi O, \& Picciotto MR (2007) Cytisine, a partial agonist of high-affinity nicotinic acetylcholine receptors, has antidepressant-like properties in male C57BL/6J mice. Neuropharmacology, 52, 1256-1262.

[121] Rabenstein RL, Caldarone BJ, \& Picciotto MR (2006) The nicotinic antagonist mecamylamine has antidepressantlike effects in wild-type but not beta2- or alpha7-nicotinic acetylcholine receptor subunit knockout mice. Psychopharmacology (Berl), 189, 395-401.

[122] Turner JR, Castellano LM, \& Blendy JA (2010) Nicotinic partial agonists varenicline and sazetidine-A have differential effects on affective behavior. J Pharmacol Exp Ther, 334, 665-672.

[123] Rollema H, Hajos M, Seymour PA, Kozak R, Majchrzak MJ, Guanowsky V, Horner WE, Chapin DS, Hoffmann WE, Johnson DE, McLean S, Freeman J, \& Williams KE (2009) Preclinical pharmacology of the alpha4beta $2 \mathrm{nAChR}$ partial agonist varenicline related to effects on reward, mood and cognition. Biochem Pharmacol, 78, 813-824.

[124] Rollema H, Guanowsky V, Mineur YS, Shrikhande A, Coe JW, Seymour PA, \& Picciotto MR (2009) Varenicline has antidepressant-like activity in the forced swim test and augments sertraline's effect. Eur J Pharmacol, 605, 114-116.

[125] Tizabi Y, Overstreet DH, Rezvani AH, Louis VA, Clark E Jr, Janowsky DS, \& Kling MA (1999) Antidepressant effects of nicotine in an animal model of depression. Psychopharmacology (Berl), 142, 193-199.

[126] Schapira AH (2007) Treatment options in the modern management of Parkinson disease. Arch Neurol, 64, 1083-1088.

[127] Meyer PM, Strecker K, Kendziorra K, Becker G, Hesse S, Woelpl D, Hensel A, Patt M, Sorger D, Wegner F, Lobsien D, Barthel H, Brust P, Gertz HJ, Sabri O, \& Schwarz J (2009) Reduced alpha4beta $2 *$-nicotinic acetylcholine receptor binding and its relationship to mild cognitive and depressive symptoms in Parkinson disease. Arch Gen Psychiatry, 66, 866-877.

[128] Fredholm BB, Chen JF, Cunha RA, Svenningsson P, \& Vaugeois JM (2005) Adenosine and brain function. Int Rev Neurobiol, 63, 191-270. 
[129] Olah ME, \& Stiles GL (2000) The role of receptor structure in determining adenosine receptor activity. Pharmacol Ther, 85, 55-75.

[130] Svenningsson P, Le Moine C, Fisone G, \& Fredholm BB (1999) Distribution, biochemistry and function of striatal adenosine A2A receptors. Prog Neurobiol, 59, 355396.

[131] Fenu S, Pinna A, Ongini E, \& Morelli M (1997) Adenosine A2A receptor antagonism potentiates LDOPA-induced turning behaviour and c-fos expression in 6-hydroxydopamine-lesioned rats. Eur J Pharmacol, 321, 143-147.

[132] Pinna A, Fenu S, \& Morelli M (2001) Motor stimulant effects of the adenosine A2A receptor antagonist $\mathrm{SCH}$ 58261 do not develop tolerance after repeated treatments in 6-hydroxydopamine-lesioned rats. Synapse, 39, 233238.

[133] Tronci E, Simola N, Borsini F, Schintu N, Frau L, Carminati P, \& Morelli M (2007) Characterization of the antiparkinsonian effects of the new adenosine $\mathrm{A} 2 \mathrm{~A}$ receptor antagonist ST1535: Acute and subchronic studies in rats. Eur J Pharmacol, 566, 94-102.

[134] Ikeda K, Kurokawa M, Aoyama S, \& Kuwana Y (2002) Neuroprotection by adenosine A2A receptor blockade in experimental models of Parkinson's disease. J Neurochem, 80, 262-270.

[135] Carta AR, Kachroo A, Schintu N, Xu K, Schwarzschild MA, Wardas J, \& Morelli M (2009) Inactivation of neuronal forebrain A receptors protects dopaminergic neurons in a mouse model of Parkinson's disease. J Neurochem, 111 , 1478-1489.

[136] Minor TR, Chang WC, \& Winslow JL (1994) Stress and adenosine: I. Effect of methylxanthine and amphetamine stimulants on learned helplessness in rats. Behav Neurosci, 108, 254-264

[137] Woodson JC, Minor TR, \& Job RF (1998) Inhibition of adenosine deaminase by erythro-9-(2-hydroxy-3nonyl)adenine (EHNA) mimics the effect of inescapable shock on escape learning in rats. Behav Neurosci, 112, 399409.

[138] Kulkarni SK, \& Mehta AK (1985) Purine nucleosidemediated immobility in mice: Reversal by antidepressants. Psychopharmacology (Berl), 85, 460-463.

[139] El Yacoubi M, Ledent C, Parmentier M, Bertorelli R, Ongini E, Costentin J, \& Vaugeois JM (2001) Adenosine A2A receptor antagonists are potential antidepressants: Evidence based on pharmacology and A2A receptor knockout mice. Br J Pharmacol, 134, 68-77.

[140] Hodgson RA, Bertorelli R, Varty GB, Lachowicz JE, Forlani A, Fredduzzi S, Cohen-Williams ME, Higgins GA, Impagnatiello F, Nicolussi E, Parra LE, Foster C, Zhai Y, Neustadt BR, Stamford AW, Parker EM, Reggiani A, \& Hunter JC (2009) Characterization of the potent and highly selective A2A receptor antagonists preladenant and SCH 412348 [7-[2-[4-2,4-difluorophenyl]1-piperazinyl]ethyl]-2-(2-furanyl)-7H-pyrazol $\mathrm{o}[4,3-\mathrm{e}][1,2,4]$ triazolo[1,5-c]pyrimidin-5-amine $]$ in rodent models of movement disorders and depression. $J$ Pharmacol Exp Ther, 330, 294-303.

[141] Krishnan V, \& Nestler EJ (2008) The molecular neurobiology of depression. Nature, $\mathbf{4 5 5}, 894-902$.

[142] McEwen BS (2008) Central effects of stress hormones in health and disease: Understanding the protective and damaging effects of stress and stress mediators. Eur J Pharmacol, $\mathbf{5 8 3}, 174-185$.
[143] Arborelius L, Owens MJ, Plotsky PM, \& Nemeroff CB (1999) The role of corticotropin-releasing factor in depression and anxiety disorders. $J$ Endocrinol, 160, 1-12.

[144] Holsboer F (2001) Stress, hypercortisolism and corticosteroid receptors in depression: Implications for therapy. $J$ Affect Disord, 62, 77-91.

[145] Noble RE (2005) Depression in women. Metabolism, 54, 49-52.

[146] Bekku N, Yoshimura H, \& Araki H (2006) Factors producing a menopausal depressive-like state in mice following ovariectomy. Psychopharmacology (Berl), 187, 170-180.

[147] Beckley EH, \& Finn DA (2007) Inhibition of progesterone metabolism mimics the effect of progesterone withdrawal on forced swim test immobility. Pharmacol Biochem Behav, 87, 412-419.

[148] George MS, Guidotti A, Rubinow D, Pan B, Mikalauskas K, \& Post RM (1994) CSF neuroactive steroids in affective disorders: Pregnenolone, progesterone, and DBI. Biol Psychiatry, 35, 775-780.

[149] Urani A, Roman FJ, Phan VL, Su TP, \& Maurice T (2001) The antidepressant-like effect induced by sigma(1)-receptor agonists and neuroactive steroids in mice submitted to the forced swimming test. J Pharmacol Exp Ther, 298, 12691279.

[150] Serra M, Pisu MG, Muggironi M, Parodo V, Papi G, Sari R, Dazzi L, Spiga F, Purdy RH, \& Biggio G (2001) Opposite effects of short- versus long-term administration of fluoxetine on the concentrations of neuroactive steroids in rat plasma and brain. Psychopharmacology (Berl), 158, 48-54.

[151] Marx CE, Shampine LJ, Khisti RT, Trost WT, Bradford DW, Grobin AC, Massing MW, Madison RD, Butterfield MI, Lieberman JA, \& Morrow AL (2006) Olanzapine and fluoxetine administration and coadministration increase rat hippocampal pregnenolone, allopregnanolone and peripheral deoxycorticosterone: Implications for therapeutic actions. Pharmacol Biochem Behav, 84, 609-617.

[152] Uzunov DP, Cooper TB, Costa E, \& Guidotti A (1996) Fluoxetine-elicited changes in brain neurosteroid content measured by negative ion mass fragmentography. Proc Natl Acad Sci U S A, 93, 12599-12604.

[153] Khisti RT, Chopde CT, \& Jain SP (2000) Antidepressant-like effect of the neurosteroid 3alpha-hydroxy-5alpha-pregnan20-one in mice forced swim test. Pharmacol Biochem Behav, 67, 137-143.

[154] Conner JM, Lauterborn JC, Yan Q, Gall CM, \& Varon S (1997) Distribution of brain-derived neurotrophic factor (BDNF) protein and mRNA in the normal adult rat CNS: Evidence for anterograde axonal transport. $J$ Neurosci, 17, 2295-2313.

[155] Huang EJ, \& Reichardt LF (2001) Neurotrophins: Roles in neuronal development and function. Anпи Rev Neurosci, 24, 677-736.

[156] Howells DW, Porritt MJ, Wong JY, Batchelor PE, Kalnins R, Hughes AJ, \& Donnan GA (2000) Reduced BDNF mRNA expression in the Parkinson's disease substantia nigra. Exp Neurol, 166, 127-135.

[157] Mogi M, Togari A, Kondo T, Mizuno Y, Komure O, Kuno S, Ichinose H, \& Nagatsu T (1999) Brain-derived growth factor and nerve growth factor concentrations are decreased in the substantia nigra in Parkinson's disease. Neurosci Lett, 270, 45-48.

[158] Parain K, Murer MG, Yan Q, Faucheux B, Agid Y, Hirsch E, \& Raisman-Vozari R (1999) Reduced expression of brainderived neurotrophic factor protein in Parkinson's disease substantia nigra. Neuroreport, 10, 557-561. 
[159] Kohno R, Sawada H, Kawamoto Y, Uemura K, Shibasaki H, \& Shimohama S (2004) BDNF is induced by wild-type alpha-synuclein but not by the two mutants, A30P or A53T, in glioma cell line. Biochem Biophys Res Commun, 318, 113-118.

[160] Porritt MJ, Batchelor PE, \& Howells DW (2005) Inhibiting BDNF expression by antisense oligonucleotide infusion causes loss of nigral dopaminergic neurons. Exp Neurol, 192, 226-234.

[161] Baquet ZC, Bickford PC, \& Jones KR (2005) Brain-derived neurotrophic factor is required for the establishment of the proper number of dopaminergic neurons in the substantia nigra pars compacta. J Neurosci, 25, 6251-6259.

[162] Fumagalli F, Racagni G, Colombo E, \& Riva MA (2003) BDNF gene expression is reduced in the frontal cortex of dopamine transporter knockout mice. Mol Psychiatry, 8, 898-899.

[163] Baydyuk M, Nguyen MT, \& Xu B (2011) Chronic deprivation of TrkB signaling leads to selective late-onset nigrostriatal dopaminergic degeneration. Exp Neurol, 228, 118-125.

[164] Murer MG, Yan Q, \& Raisman-Vozari R (2001) Brainderived neurotrophic factor in the control human brain, and in Alzheimer's disease and Parkinson's disease. Prog $\mathrm{Neu}$ robiol, 63, 71-124.

[165] Levivier M, Przedborski S, Bencsics C, \& Kang UJ (1995) Intrastriatal implantation of fibroblasts genetically engineered to produce brain-derived neurotrophic factor prevents degeneration of dopaminergic neurons in a rat model of Parkinson's disease. J Neurosci, 15, 7810-7820.

[166] Isacson O, Deacon TW, Pakzaban P, Galpern WR, Dinsmore J, \& Burns LH (1995) Transplanted xenogeneic neural cells in neurodegenerative disease models exhibit remarkable axonal target specificity and distinct growth patterns of glial and axonal fibres. Nat Med, 1, 1189-1194.

[167] Dwivedi Y, Rizavi HS, Conley RR, Roberts RC, Tamminga CA, \& Pandey GN (2003) Altered gene expression of brainderived neurotrophic factor and receptor tyrosine kinase B in postmortem brain of suicide subjects. Arch Gen Psychiatry, 60, 804-815.

[168] Brunoni AR, Lopes M, \& Fregni F (2008) A systematic review and meta-analysis of clinical studies on major depression and BDNF levels: Implications for the role of neuroplasticity in depression. Int J Neuropsychopharmacol, 11, 1169-1180.

[169] Siuciak JA, Lewis DR, Wiegand SJ, \& Lindsay RM (1997) Antidepressant-like effect of brain-derived neurotrophic factor (BDNF). Pharmacol Biochem Behav, 56, 131-137.

[170] Shirayama Y, Chen AC, Nakagawa S, Russell DS, \& Duman RS (2002) Brain-derived neurotrophic factor produces antidepressant effects in behavioral models of depression. J Neurosci, 22, 3251-3261.

[171] Warner-Schmidt JL, \& Duman RS (2007) VEGF is an essential mediator of the neurogenic and behavioral actions of antidepressants. Proc Natl Acad Sci U S A, 104, 46474652 .

[172] Greene J, Banasr M, Lee B, Warner-Schmidt J, \& Duman RS (2009) Vascular endothelial growth factor signaling is required for the behavioral actions of antidepressant treatment: Pharmacological and cellular characterization. Neuropsychopharmacology, 34, 2459-2468.

[173] Tian YY, Tang CJ, Wang JN, Feng Y, Chen XW, Wang L, Qiao X, \& Sun SG (2007) Favorable effects of VEGF gene transfer on a rat model of Parkinson disease using adenoassociated viral vectors. Neurosci Lett, 421, 239-244.
[174] Ohlin KE, Francardo V, Lindgren HS, Sillivan SE, O'Sullivan SS, Luksik AS, Vassoler FM, Lees AJ, Konradi C, \& Cenci MA (2011) Vascular endothelial growth factor is upregulated by L-dopa in the parkinsonian brain: Implications for the development of dyskinesia. Brain, 134, 2339-2357.

[175] Eriksson PS, Perfilieva E, Bjork-Eriksson T, Alborn AM, Nordborg C, Peterson DA, \& Gage FH (1998) Neurogenesis in the adult human hippocampus. Nat Med, 4, 1313-1317.

[176] Kempermann G, \& Gage FH (2002) Genetic determinants of adult hippocampal neurogenesis correlate with acquisition, but not probe trial performance, in the water maze task. Eur J Neurosci, 16, 129-136.

[177] David DJ, Samuels BA, Rainer Q, Wang JW, Marsteller D, Mendez I, Drew M, Craig DA, Guiard BP, Guilloux JP, Artymyshyn RP, Gardier AM, Gerald C, Antonijevic IA, Leonardo ED, \& Hen R (2009) Neurogenesis-dependent and -independent effects of fluoxetine in an animal model of anxiety/depression. Neuron, 62, 479-493.

[178] Hoglinger GU, Rizk P, Muriel MP, Duyckaerts C, Oertel WH, Caille I, \& Hirsch EC (2004) Dopamine depletion impairs precursor cell proliferation in Parkinson disease. Nat Neurosci, 7, 726-735.

[179] Navailles S, Hof PR, \& Schmauss C (2008) Antidepressant drug-induced stimulation of mouse hippocampal neurogenesis is age-dependent and altered by early life stress. J Comp Neurol, 509, 372-381.

[180] Freundlieb N, Francois C, Tande D, Oertel WH, Hirsch EC, \& Hoglinger GU (2006) Dopaminergic substantia nigra neurons project topographically organized to the subventricular zone and stimulate precursor cell proliferation in aged primates. J Neurosci, 26, 2321-2325.

[181] Winner B, Desplats P, Hagl C, Klucken J, Aigner R, Ploetz S, Laemke J, Karl A, Aigner L, Masliah E, Buerger E, \& Winkler J (2009) Dopamine receptor activation promotes adult neurogenesis in an acute Parkinson model. Exp Neurol, 219, 543-552.

[182] Winner B, Lie DC, Rockenstein E, Aigner R, Aigner L, Masliah E, Kuhn HG, \& Winkler J (2004) Human wild-type alpha-synuclein impairs neurogenesis. J Neuropathol Exp Neurol, 63, 1155-1166.

[183] Crews L, Mizuno H, Desplats P, Rockenstein E, Adame A, Patrick C, Winner B, Winkler J, \& Masliah E (2008) Alpha-synuclein alters Notch-1 expression and neurogenesis in mouse embryonic stem cells and in the hippocampus of transgenic mice. J Neurosci, 28, 4250-4260.

[184] Nuber S, Petrasch-Parwez E, Winner B, Winkler J, von Horsten S, Schmidt T, Boy J, Kuhn M, Nguyen HP, Teismann P, Schulz JB, Neumann M, Pichler BJ, Reischl G, Holzmann C, Schmitt I, Bornemann A, Kuhn W, Zimmermann F, Servadio A, \& Riess O (2008) Neurodegeneration and motor dysfunction in a conditional model of Parkinson's disease. J Neurosci, 28, 2471-2484.

[185] Winner B, Rockenstein E, Lie DC, Aigner R, Mante M, Bogdahn U, Couillard-Despres S, Masliah E, \& Winkler J (2008) Mutant alpha-synuclein exacerbates age-related decrease of neurogenesis. Neurobiol Aging, 29, 913-925.

[186] Lennington JB, Pope S, Goodheart AE, Drozdowicz L, Daniels SB, Salamone JD, \& Conover JC (2011) Midbrain dopamine neurons associated with reward processing innervate the neurogenic subventricular zone. J Neurosci, 31, 13078-13087.

[187] van den Berge SA, van Strien ME, Korecka JA, Dijkstra AA, Sluijs JA, Kooijman L, Eggers R, De Filippis L, Vescovi AL, Verhaagen J, van de Berg WD, \& Hol EM (2011) The 
proliferative capacity of the subventricular zone is maintained in the parkinsonian brain. Brain, 134, 3249-3263.

[188] Winner B, Vogt-Weisenhorn DM, Lie CD, Blumcke I, \& Winkler J (2009) Cellular repair strategies in Parkinson's disease. Ther Adv Neurol Disord, 2, 51-60.

[189] Santarelli L, Saxe M, Gross C, Surget A, Battaglia F, Dulawa S, Weisstaub N, Lee J, Duman R, Arancio O, Belzung C, \& Hen R (2003) Requirement of hippocampal neurogenesis for the behavioral effects of antidepressants. Science, 301, 805-809.

[190] Radley JJ, \& Jacobs BL (2002) 5-HT1A receptor antagonist administration decreases cell proliferation in the dentate gyrus. Brain Res, 955, 264-267.

[191] Banasr M, Hery M, Printemps R, \& Daszuta A (2004) Serotonin-induced increases in adult cell proliferation and neurogenesis are mediated through different and common 5-HT receptor subtypes in the dentate gyrus and the subventricular zone. Neuropsychopharmacology, 29, 450460.

[192] Gao HM, Hong JS, Zhang W, \& Liu B (2002) Distinct role for microglia in rotenone-induced degeneration of dopaminergic neurons. J Neurosci, 22, 782-790.

[193] Cicchetti F, Brownell AL, Williams K, Chen YI, Livni E, \& Isacson O (2002) Neuroinflammation of the nigrostriatal pathway during progressive 6-OHDA dopamine degeneration in rats monitored by immunohistochemistry and PET imaging. Eur J Neurosci, 15, 991-998.

[194] Gao HM, Jiang J, Wilson B, Zhang W, Hong JS, \& Liu B (2002) Microglial activation-mediated delayed and progressive degeneration of rat nigral dopaminergic neurons: Relevance to Parkinson's disease. J Neurochem, 81, 12851297.

[195] Castano A, Herrera AJ, Cano J, \& Machado A (1998) Lipopolysaccharide intranigral injection induces inflammatory reaction and damage in nigrostriatal dopaminergic system. J Neurochem, 70, 1584-1592.

[196] Herrera AJ, Castano A, Venero JL, Cano J, \& Machado A (2000) The single intranigral injection of LPS as a new model for studying the selective effects of inflammatory reactions on dopaminergic system. Neurobiol Dis, 7, 429447.

[197] Allan SM, \& Rothwell NJ (2001) Cytokines and acute neurodegeneration. Nat Rev Neurosci, 2, 734-744.

[198] Sriram K, Miller DB, \& O'Callaghan JP (2006) Minocycline attenuates microglial activation but fails to mitigate striatal dopaminergic neurotoxicity: Role of tumor necrosis factoralpha. J Neurochem, 96, 706-718.

[199] Feng ZH, Wang TG, Li DD, Fung P, Wilson BC, Liu B, Ali SF, Langenbach R, \& Hong JS (2002) Cyclooxygenase2-deficient mice are resistant to 1-methyl-4-phenyl1, 2, 3, 6-tetrahydropyridine-induced damage of dopaminergic neurons in the substantia nigra. Neurosci Lett, 329, 354-358.

[200] Sairam K, Saravanan KS, Banerjee R, \& Mohanakumar KP (2003) Non-steroidal anti-inflammatory drug sodium salicylate, but not diclofenac or celecoxib, protects against 1-methyl-4-phenyl pyridinium-induced dopaminergic neurotoxicity in rats. Brain Res, $\mathbf{9 6 6}, 245-252$.

[201] Teismann P, \& Ferger B (2001) Inhibition of the cyclooxygenase isoenzymes COX-1 and COX-2 provide neuroprotection in the MPTP-mouse model of Parkinson's disease. Synapse, 39, 167-174

[202] Du Y, Ma Z, Lin S, Dodel RC, Gao F, Bales KR, Triarhou LC, Chernet E, Perry KW, Nelson DL, Luecke S, Phebus LA, Bymaster FP, \& Paul SM (2001) Minocycline prevents nigrostriatal dopaminergic neurodegeneration in the MPTP model of Parkinson's disease. Proc Natl Acad Sci U S A, 98, 14669-14674.

[203] He Y, Appel S, \& Le W (2001) Minocycline inhibits microglial activation and protects nigral cells after 6hydroxydopamine injection into mouse striatum. Brain Res, 909, 187-193.

[204] Wu DC, Jackson-Lewis V, Vila M, Tieu K, Teismann P, Vadseth C, Choi DK, Ischiropoulos H, \& Przedborski S (2002) Blockade of microglial activation is neuroprotective in the 1-methyl-4-phenyl-1,2,3,6-tetrahydropyridine mouse model of Parkinson disease. J Neurosci, 22, 1763-1771.

[205] Tomas-Camardiel M, Rite I, Herrera AJ, de Pablos RM, Cano J, Machado A, \& Venero JL (2004) Minocycline reduces the lipopolysaccharide-induced inflammatory reaction, peroxynitrite-mediated nitration of proteins, disruption of the blood-brain barrier, and damage in the nigral dopaminergic system. Neurobiol Dis, 16, 190-201.

[206] Maes M (1993) A review on the acute phase response in major depression. Rev Neurosci, 4, 407-416.

[207] Maes M (2008) The cytokine hypothesis of depression: Inflammation, oxidative \& nitrosative stress (IO\&NS) and leaky gut as new targets for adjunctive treatments in depression. Neuro Endocrinol Lett, 29, 287-291.

[208] Maes M, Smith R, \& Scharpe S (1995) The monocyteT-lymphocyte hypothesis of major depression. Psychoneuroendocrinology, 20, 111-116.

[209] Maes M, Yirmyia R, Noraberg J, Brene S, Hibbeln J, Perini G, Kubera M, Bob P, Lerer B, \& Maj M (2009) The inflammatory \& neurodegenerative (I\&ND) hypothesis of depression: Leads for future research and new drug developments in depression. Metab Brain Dis, 24, 27-53.

[210] Miller AH, Maletic V, \& Raison CL (2009) Inflammation and its discontents: The role of cytokines in the pathophysiology of major depression. Biol Psychiatry, 65, 732-741.

[211] De La Garza R, 2nd (2005) Endotoxin- or pro-inflammatory cytokine-induced sickness behavior as an animal model of depression: Focus on anhedonia. Neurosci Biobehav Rev, 29, 761-770.

[212] Dunn AJ, \& Swiergiel AH (2005) Effects of interleukin-1 and endotoxin in the forced swim and tail suspension tests in mice. Pharmacol Biochem Behav, 81, 688-693.

[213] Goshen I, Kreisel T, Ben-Menachem-Zidon O, Licht T, Weidenfeld J, Ben-Hur T, \& Yirmiya R (2008) Brain interleukin-1 mediates chronic stress-induced depression in mice via adrenocortical activation and hippocampal neurogenesis suppression. Mol Psychiatry, 13, 717-728.

[214] Dobos N, de Vries EF, Kema IP, Patas K, Prins M, Nijholt IM, Dierckx RA, Korf J, den Boer JA, Luiten PG, Eisel UL (2011) The role of indoleamine 2, 3-dioxygenase in a mouse model of neuroinflammation-induced depression. $J$ Alzheimers Dis, 28(4), 905-915.

[215] Zhu CB, Lindler KM, Owens AW, Daws LC, Blakely RD, \& Hewlett WA (2010) Interleukin-1 receptor activation by systemic lipopolysaccharide induces behavioral despair linked to MAPK regulation of CNS serotonin transporters. $\mathrm{Neu}$ ropsychopharmacology, 35, 2510-2520.

[216] Barr AM, Song C, Sawada K, Young CE, Honer WG, \& Phillips AG (2003) Tolerance to the anhedonic effects of lipopolysaccharide is associated with changes in syntaxin immunoreactivity in the nucleus accumbens. Int J Neuropsychopharmacol, 6, 23-34.

[217] Connor TJ, Song C, Leonard BE, Anisman H, \& Merali Z (1999) Stressor-induced alterations in serotonergic activity in an animal model of depression. Neuroreport, 10, 523528. 
[218] Yirmiya R, Pollak Y, Barak O, Avitsur R, Ovadia H, Bette M, Weihe E, \& Weidenfeld J (2001) Effects of antidepressant drugs on the behavioral and physiological responses to lipopolysaccharide (LPS) in rodents. Neuropsychopharmacology, 24, 531-544.

[219] Castanon N, Bluthe RM, \& Dantzer R (2001) Chronic treatment with the atypical antidepressant tianeptine attenuates sickness behavior induced by peripheral but not central lipopolysaccharide and interleukin-1beta in the rat. Psychopharmacology (Berl), 154, 50-60.

[220] Song C, \& Wang H (2011) Cytokines mediated inflammation and decreased neurogenesis in animal models of depression. Prog Neuropsychopharmacol Biol Psychiatry, 35, 760-768.

[221] Vallieres L, Campbell IL, Gage FH, \& Sawchenko PE (2002) Reduced hippocampal neurogenesis in adult transgenic mice with chronic astrocytic production of interleukin-6. J Neurosci, 22, 486-492.

[222] Monje ML, Toda H, \& Palmer TD (2003) Inflammatory blockade restores adult hippocampal neurogenesis. Science, 302, 1760-1765.

[223] Battista D, Ferrari CC, Gage FH, \& Pitossi FJ (2006) Neurogenic niche modulation by activated microglia: Transforming growth factor beta increases neurogenesis in the adult dentate gyrus. Eur J Neurosci, 23, 83-93.

[224] Limousin P, Krack P, Pollak P, Benazzouz A, Ardouin C, Hoffmann D, \& Benabid AL (1998) Electrical stimulation of the subthalamic nucleus in advanced Parkinson's disease. N Engl J Med, 339, 1105-1111.

[225] Voon V, Sohr M, Lang AE, Potenza MN, Siderowf AD, Whetteckey J, Weintraub D, Wunderlich GR, \& Stacy M (2011) Impulse control disorders in Parkinson disease: A multicenter case-control study. Ann Neurol, 69, 986-996.

[226] Tan SK, Hartung H, Sharp T, \& Temel Y (2011) Serotonindependent depression in Parkinson's disease: A role for the subthalamic nucleus? Neuropharmacology, 61, 387-399.
[227] Mayberg HS, Lozano AM, Voon V, McNeely HE, Seminowicz D, Hamani C, Schwalb JM, \& Kennedy SH (2005) Deep brain stimulation for treatment-resistant depression. Neuron, 45, 651-660.

[228] Bewernick BH, Hurlemann R, Matusch A, Kayser S, Grubert C, Hadrysiewicz B, Axmacher N, Lemke M, Cooper-Mahkorn D, Cohen MX, Brockmann H, Lenartz D, Sturm V, \& Schlaepfer TE (2010) Nucleus accumbens deep brain stimulation decreases ratings of depression and anxiety in treatment-resistant depression. Biol Psychiatry, 67, 110-116.

[229] Fisher BE, Petzinger GM, Nixon K, Hogg E, Bremmer S, Meshul CK, \& Jakowec MW (2004) Exercise-induced behavioral recovery and neuroplasticity in the 1-methyl4-phenyl-1,2,3,6-tetrahydropyridine-lesioned mouse basal ganglia. J Neurosci Res, 77, 378-390.

[230] Petzinger GM, Walsh JP, Akopian G, Hogg E, Abernathy A, Arevalo P, Turnquist P, Vuckovic M, Fisher BE, Togasaki DM, \& Jakowec MW (2007) Effects of treadmill exercise on dopaminergic transmission in the 1-methyl-4-phenyl1,2,3,6-tetrahydropyridine-lesioned mouse model of basal ganglia injury. J Neurosci, 27, 5291-5300.

[231] Tillerson JL, Caudle WM, Reveron ME, \& Miller GW (2003) Exercise induces behavioral recovery and attenuates neurochemical deficits in rodent models of Parkinson's disease. Neuroscience, 119, 899-911.

[232] Duman CH, Schlesinger L, Russell DS, \& Duman RS (2008) Voluntary exercise produces antidepressant and anxiolytic behavioral effects in mice. Brain Res, 1199, 148-158.

[233] Gorton LM, Vuckovic MG, Vertelkina N, Petzinger GM, Jakowec MW, \& Wood RI (2010) Exercise effects on motor and affective behavior and catecholamine neurochemistry in the MPTP-lesioned mouse. Behav Brain Res, 213, 253-262. 